\title{
Composition, distribution and biomass of meiobenthos in the Oosterschelde estuary (SW Netherlands)
}

\author{
N. Smol ${ }^{1}$, K. A. Willems ${ }^{1,3}$, J. C. R. Govaere ${ }^{2}$ \& A. J. J. Sandee ${ }^{3}$ \\ ${ }^{1}$ Marine Biology Section, State University of Ghent, Ledeganckstraat 35, 9000 Gent, Belgium; \\ ${ }^{2}$ Koninklijk Belgisch Instituut voor Natuurwetenschappen, Vautierstraat 29, 1040 Brussel, Belgium; \\ ${ }^{3}$ Netherlands Institute of Ecology, Vierstraat 28, 4401 EA Yerseke, The Netherlands
}

Key words: meiofauna, distribution, biomass, seasonal variation, Oosterschelde estuary

\begin{abstract}
Meiofauna composition, abundance, biomass, distribution and diversity were investigated for 31 stations in summer. The sampling covered the whole Oosterschelde and comparisons between the subtidal intertidal and between the western-central - eastern compartment were made.

Meiofauna had a community density ranging between 200 and 17500 ind $10 \mathrm{~cm}^{-2}$, corresponding to a dry weight of 0.2 and $8.4 \mathrm{gm}^{-2}$. Abundance ranged between 130 and 17200 ind $10 \mathrm{~cm}^{-2}$ for nematodes and between 10 and 1600 ind $10 \mathrm{~cm}^{-2}$ for copepods. Dry weight biomass of these taxa was between $0.5-7.0 \mathrm{gm}^{-2}$ and $0.008-0.3 \mathrm{gm}^{-2}$ for nematodes and copepods respectively.

The meiofauna was strongly dominated by the nematodes (36-99\%), who's abundance, biomass and diversity were significantly higher intertidally than subtidally and significantly higher in the eastern part than in the western part. High numbers were positively correlated with the percentage silt and negatively with the median grain size of the sand fraction. The abundance and diversity of the copepods were highest in the subtidal, but their biomass showed an inverse trend being highest on the tidal flats.

The taxa diversity of the meiofauna community and species diversity of both the nematodes and the copepods were higher in subtidal stations than on tidal flats. In the subtidal, the meiofauna and copepod diversity decreased from west to east, whereas nematode diversity increased.

The vertical profile clearly reflected the sediment characteristics and could be explained by local hydrodynamic conditions.

Seasonal variation was pronounced for the different taxa with peak abundance in spring, summer or autumn and minimun abundance in winter.

Changes in tidal amplitude and current velocity enhanced by the storm-surge barrier will alter the meiofauna community structure. As a result meiofauna will become more important in terms of density and biomass, mainly due to increasing numbers of nematodes, increasing bioturbation, nutrient mineralisation and sustaining bacterial growth. A general decrease in meiofauna diversity is predicted. The number of copepods is expected to decrease and interstitial species will be replaced by epibenthic species, the latter being more important in terms of biomass and as food for the epibenthic macrofauna and fishes.
\end{abstract}




\section{Introduction}

Meiofauna is defined here as the benthic Metazoa that can pass through a sieve with a mesh size of $1 \mathrm{~mm}$ and comprises the benthic animals intermediate between the microfaunal organisms (bacteria, ciliates, foraminiferans etc.) and the macrofaunal organisms (polychaetes, bivalves, crustaceans etc.).

Meiobenthos occur in all types of sediment and occupy a wide variety of habitats. In general, grain size of the sediment is a primary factor affecting the abundance and species composition of meiobenthic organisms.

Meiofauna has been investigated in different estuaries: e.g. Blyth, England (Capstick, 1959), Elbe, Germany (Riemann, 1966), New England, USA. (Tietjen, 1969), Exe, England (Warwick, 1971), Weser, Germany (Skoolmun \& Gerlach, 1971), Grevelingen, the Netherlands (Heip et al., 1977; Willems \& Sandee, 1978, 1979; Willems et al., 1984), Tigris \& Euphrate, Iraq (Saad \& Arlt, 1977; Arlt \& Saad, 1977), Swartskop, S. Africa (Dye \& Furstenberg, 1978), Lynher, England (Warwick \& Price, 1979), Westerschelde, the Netherlands, Belgium (Heip et al., 1979; Van Damme et al., 1980; Van Damme et al., 1984), Eems-Dollard, the Netherlands (Heip et al., 1979; Van Es et al., 1980; Bouwman, 1983; Van Damme et al., 1984), the Wadden Sea, the Netherlands (Witte \& Zijlstra, 1984), Wellington, New Zealand (Coull \& Wells, 1981), Ythan, Scotland (Baird \& Milne,1981), Tamar, England (Warwick \& Gee, 1984; Austen \& Warwick, 1989), Hunter, Australia (Hodda \& Nicholas, 1985, 1986).

Meiobenthos of the Oosterschelde was extensively sampled during the period 1976-1985, the period before and during the construction of the storm-surge barrier. Due to the construction of different barriers the estuarine character of the Oosterschelde is mainly lost and the salinity is fairly constant: $28-30 \%$. (Wolff, 1973; Duursma et al., 1982). The Oosterschelde is nowadays characterized as a polyhaline or mixo-euhaline sea arm or tidal bay (Nienhuis \& Smaal, 1994).

Preliminary results on the Oosterschelde meiofauna are given by Heip et al., 1979 and Smol,
1986. This paper deals with extensive information on the spatial and seasonal distribution, density, biomass and diversity of the whole meiofauna with special focus on the two dominant taxa: nematodes and copepods.

\section{Material and methods}

\section{Sampling}

The meiofauna composition of 31 stations was investigated, covering both the subtidal and the intertidal habitats of the whole Oosterschelde area and covering different substrate types (Fig. 1). Most stations, 01 to 024 , were sampled in August-September 1981. Station 017 was sampled in August 1981; station 035 in June 1984 and the stations 036a, 036b, 036c, 037a, 037b, $037 \mathrm{c}, 038 \mathrm{a}, 038 \mathrm{~b}$ and $038 \mathrm{c}$ were sampled in May, August, November 1984 and February 1985 to investigate temporal changes in meiofauna community. The coordinates and depth at the moment of sampling of the stations are represented in Table 1. The first three samples were located west of the storm-surge barrier.

Sublittoral samples were collected with a modified 'Reineck box-corer' (Farris \& Crezee, 1976) of which 5 replicate subsamples were taken with a $10 \mathrm{~cm}^{2}$ perspex corer of $40 \mathrm{~cm}$ length. Stations $36 \mathrm{~b}, 37 \mathrm{~b}$ and $38 \mathrm{~b}$ at $-1 \mathrm{~m}$ depth below low water level were sampled with a hand held $10 \mathrm{~cm}^{2}$ perspex corer using SCUBA-diving; the same corer was also used in collecting intertidal samples at low tide. At each station 4 replicate samples were analyzed for meiofauna and 1 for sediment. On some tidal flats (e.g. 017, 024, 028) samples were taken on 4 different places situated along a transect perpendicular to the water line; those data were pooled together and a mean value of the 4 samples is taken as representative for that intertidal station.

Sediment granulometry was determined using a graded series of standard sieves suited to the intervals of the Wenthworth scale (Buchanan \& Kain, 1971). The degree of sorting was classified according to Wolff (1973). The silt fraction was determined as the amount of sediment passing 


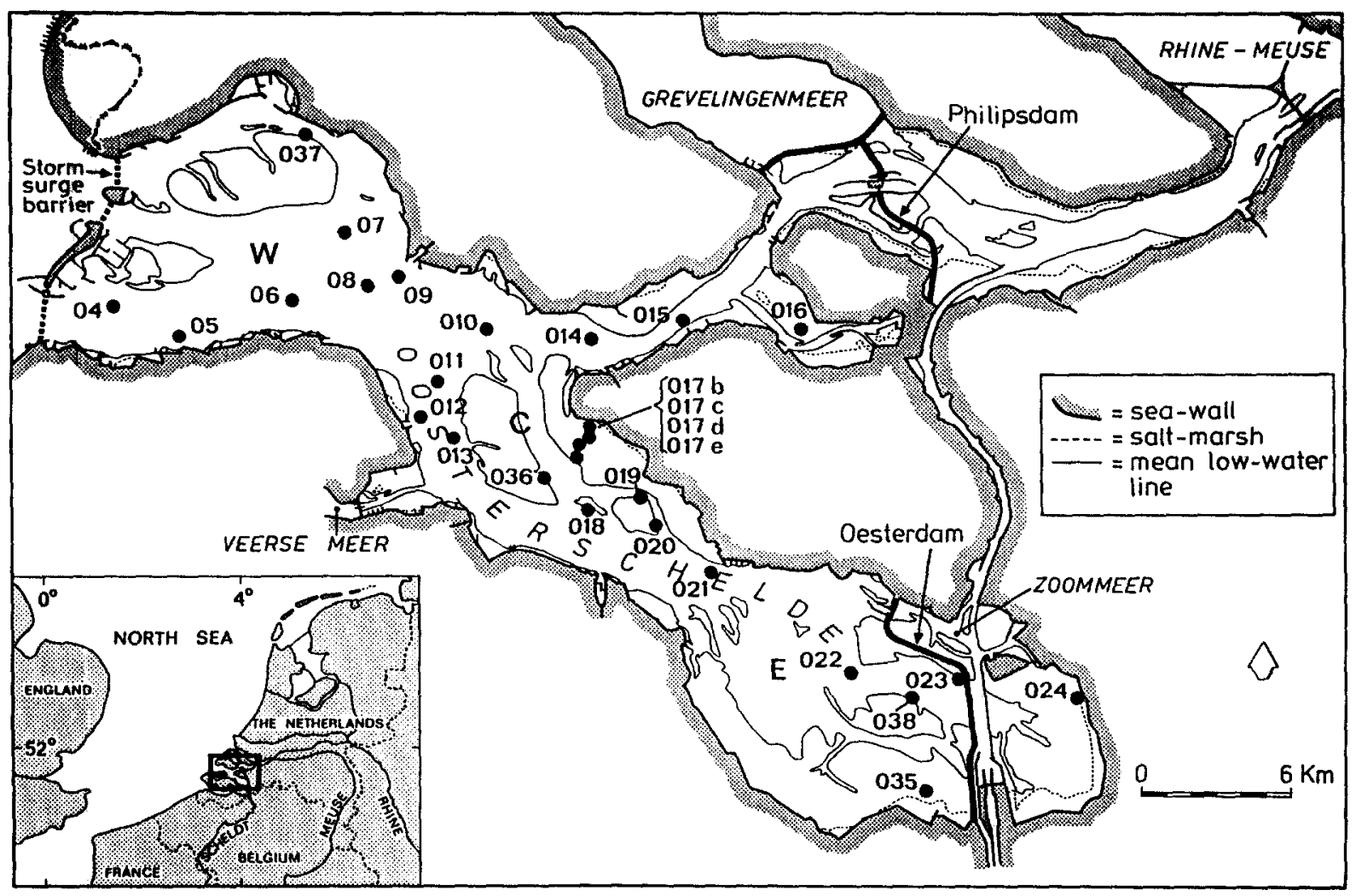

Fig. 1. Location of the stations in Oosterschelde estuary.

through the $62 \mu \mathrm{m}$ sieves and the gravel fraction as the amount of material retained on the $1 \mathrm{~mm}$ sieve.

Copepods and nematodes were elutriated from the sand on a $38 \mu \mathrm{m}$ sieve using a combination of the trough-method (Barnett, 1968) and a density gradient centrifugation technique with ludox HS $40 \%$ (Bowen et al., 1972). All copepods were identified. Because of the high numbers of nematodes, only 100 chosen at random were identified to species level.

For the stations 036a, 036b, 036c, 037a, 037b, $037 \mathrm{c}, 038 \mathrm{a}, 038 \mathrm{~b}, 038 \mathrm{c}$ mean individual dry weight of the nematodes and copepods was determined by means of a Mettler microbalance (accuracy $0.1 \mu \mathrm{g}$ ). Two hundred nematodes or twenty copepods, randomly picked out and rinsed with distilled water, were transferred to an aluminium vial and weighed after two hours of drying and 30 minutes of cooling.

For the other stations a value of $0.38 \mu \mathrm{g}$ (mean individual dry weight in summer) was used for the nematodes and individual dry weight of the copepods was determined by the method of Willems (1989). The individual dry weight of the other meiofauna taxa was based on values presented by Faubel (1982) and Van Damme et al. (1980); a mean value of the different size classes was used.

The following individual dry weight values were used to calculate the total biomass of the different groups: Turbellaria: $3.7 \mu \mathrm{g}$, Ostracoda: $7.8 \mu \mathrm{g}$, Gastrotricha: $0.43 \mu \mathrm{g}$, Archiannelida: $4.6 \mu \mathrm{g}, \mathrm{Hy}-$ drozoa: $3.0 \mu \mathrm{g}$, Halacarida: $1.8 \mu \mathrm{g}$, Tardigrada: $0.7 \mu \mathrm{g}$, Kinorhyncha: $2.1 \mu \mathrm{g}$, Polychaeta: $4.6 \mu \mathrm{g}$, Oligochaeta: $3.6 \mu \mathrm{g}$, Nemertini: $14.1 \mu \mathrm{g}$, Cumacea: $10 \mu \mathrm{g}$, Tanaidacea: $10 \mu \mathrm{g}$ and Bivalvia: $5.4 \mu \mathrm{g}$.

\section{Statistics}

For statistical analysis only the values of the stations sampled in August and early September 
Table 1. Geographic coordinates, depth and sediment characteristics of the stations.

\begin{tabular}{|c|c|c|c|c|c|c|c|}
\hline \multirow[t]{2}{*}{ Station } & \multirow{2}{*}{$\begin{array}{l}\text { Latitude } \\
\text { North }\end{array}$} & \multirow{2}{*}{$\begin{array}{l}\text { Longitude } \\
\text { East }\end{array}$} & \multirow{2}{*}{$\begin{array}{l}\text { Depth } \\
\mathrm{m}\end{array}$} & \multicolumn{4}{|c|}{ Sediment characteristics } \\
\hline & & & & Grain size $(\mu \mathrm{m})$ & Sorting & $\%$ silt & $\%$ gravel \\
\hline 01 & $51^{\circ} 37^{\prime} 42^{\prime \prime}$ & $3^{\circ} 19^{\prime} 02^{\prime \prime}$ & -10 & 308 & 0.350 & 0.15 & 0.00 \\
\hline $\mathrm{O} 2$ & $51^{\circ} 40^{\prime} 13^{\prime \prime}$ & $3^{\circ} 31^{\prime} 14^{\prime \prime}$ & -5 & 275 & 0.340 & 0.20 & 0.00 \\
\hline $\mathrm{O} 2$ & $51^{\circ} 37^{\prime} 58^{\prime \prime}$ & $3^{\circ} 26^{\prime} 33^{\prime \prime}$ & -11 & 394 & 0.410 & 0.28 & 0.00 \\
\hline $\mathrm{O} 4$ & $51^{\circ} 38^{\prime} 28^{\prime \prime}$ & $3^{\circ} 43^{\prime} 16^{\prime \prime}$ & -23 & 202 & 0.360 & 0.24 & 0.00 \\
\hline O5 & $51^{\circ} 36^{\prime} 25^{\prime \prime}$ & $3^{\circ} 45^{\prime} 45^{\prime \prime}$ & -24 & 257 & 0.310 & 0.00 & 0.00 \\
\hline O6 & $51^{\circ} 37^{\prime} 02^{\prime \prime}$ & $3^{\circ} 49^{\prime} 48^{\prime \prime}$ & -10 & 180 & 0.320 & 0.96 & 0.00 \\
\hline O7 & $51^{\circ} 38^{\prime} 47^{\prime \prime}$ & $3^{\circ} 51^{\prime} 37^{\prime \prime}$ & -16 & 260 & 0.350 & 0.15 & 0.00 \\
\hline 08 & $51^{\circ} 37^{\prime} 29^{\prime \prime}$ & $3^{\circ} 52^{\prime} 33^{\prime \prime}$ & -6 & 210 & 0.360 & 0.39 & 0.00 \\
\hline O9 & $51^{\circ} 37^{\prime} 51^{\prime \prime}$ & $3^{\circ} 53^{\prime} 32^{\prime \prime}$ & -55 & 240 & 0.360 & 0.33 & 0.00 \\
\hline 010 & $51^{\circ} 36^{\prime} 62^{\prime \prime}$ & $3^{\circ} 56^{\prime} 32^{\prime \prime}$ & -21 & 246 & 0.340 & 0.12 & 0.00 \\
\hline O11 & $51^{\circ} 35^{\prime} 29^{\prime \prime}$ & $3^{\circ} 54^{\prime} 59^{\prime \prime}$ & -11 & 251 & 0.520 & 1.43 & 0.00 \\
\hline $\mathrm{O} 12$ & $51^{\circ} 34^{\prime} 17^{\prime \prime}$ & $3^{\circ} 54^{\prime} 05^{\prime \prime}$ & -36 & 333 & 0.390 & 0.48 & 4.51 \\
\hline 013 & $51^{\circ} 34^{\prime} 09^{\prime \prime}$ & $3^{\circ} 55^{\prime} 04^{\prime \prime}$ & -11 & 219 & 0.330 & 0.57 & 0.00 \\
\hline O14 & $51^{\circ} 36^{\prime} 13^{\prime \prime}$ & $4^{\circ} 00^{\prime} 01^{\prime \prime}$ & -16 & 242 & 0.340 & 0.00 & 2.93 \\
\hline 015 & $51^{\circ} 36^{\prime} 56^{\prime \prime}$ & $4^{\circ} 03^{\prime} 09^{\prime \prime}$ & -20 & 278 & 0.320 & 0.19 & 0.56 \\
\hline 016 & $51^{\circ} 36^{\prime} 28^{\prime \prime}$ & $4^{\circ} 07^{\prime} 26^{\prime \prime}$ & -6 & 161 & 0.450 & 8.65 & 1.91 \\
\hline $\mathrm{O} 17$ & $51^{\circ} 34^{\prime} 49^{\prime \prime}$ & $4^{\circ} 00^{\prime} 25^{\prime \prime}$ & 0 & 159 & 0.355 & 1.80 & 0.00 \\
\hline O18 & $51^{\circ} 33^{\prime} 15^{\prime \prime}$ & $4^{\circ} 00^{\prime} 00^{\prime \prime}$ & -3 & 157 & 0.240 & 0.28 & 0.00 \\
\hline O19 & $51^{\circ} 33^{\prime} 25^{\prime \prime}$ & $4^{\circ} 02^{\prime} 02^{\prime \prime}$ & -10 & 127 & 0.300 & 16.94 & 0.00 \\
\hline $\mathrm{O} 20$ & $51^{\circ} 32^{\prime} 22^{\prime \prime}$ & $4^{\circ} 02^{\prime} 43^{\prime \prime}$ & -8 & 116 & 0.360 & 16.38 & 2.24 \\
\hline $\mathrm{O} 21$ & $51^{\circ} 31^{\prime} 20^{\prime \prime}$ & $4^{\circ} 04^{\prime} 36^{\prime \prime}$ & -41 & 278 & 0.400 & 0.21 & 0.00 \\
\hline $\mathrm{O} 22$ & $51^{\circ} 29^{\prime} 12^{\prime \prime}$ & $4^{\circ} 09^{\prime} 02^{\prime \prime}$ & -18 & 151 & 0.400 & 2.05 & 0.00 \\
\hline $\mathrm{O} 23$ & $51^{\circ} 29^{\prime} 01^{\prime \prime}$ & $4^{\circ} 13^{\prime} 27^{\prime \prime}$ & -6 & 186 & 0.760 & 20.52 & 0.00 \\
\hline $\mathrm{O} 24$ & $51^{\circ} 27^{\prime} 29^{\prime \prime}$ & $4^{\circ} 16^{\prime} 07^{\prime \prime}$ & 0 & 111 & 0.550 & 29.25 & 0.00 \\
\hline O35 & $51^{\circ} 26^{\prime} 22^{\prime \prime}$ & $4^{\circ} 10^{\prime} 06^{\prime \prime}$ & 0 & 125 & 0.375 & 5.40 & 0.00 \\
\hline O36a & $51^{\circ} 33^{\prime} 24^{\prime \prime}$ & $3^{\circ} 58^{\prime} 28^{\prime \prime}$ & 0 & 137 & 0.270 & 3.20 & \\
\hline $\mathrm{O} 36 \mathrm{~b}$ & $51^{\circ} 33^{\prime} 24^{\prime \prime}$ & $3^{\circ} 58^{\prime} 28^{\prime \prime}$ & -1 & 131 & 0.300 & 2.90 & \\
\hline O37a & $51^{\circ} 40^{\prime} 24^{\prime \prime}$ & $3^{\circ} 50^{\prime} 14^{\prime \prime}$ & 0 & 147 & 0.330 & 6.00 & \\
\hline $\mathrm{O} 37 \mathrm{~b}$ & $51^{\circ} 40^{\prime} 24^{\prime \prime}$ & $3^{\circ} 50^{\prime} 14^{\prime \prime}$ & -1 & 129 & 0.460 & 16.10 & \\
\hline O38a & $51^{\circ} 28^{\prime} 52^{\prime \prime}$ & $4^{\circ} 11^{\prime} 15^{\prime \prime}$ & 0 & 139 & 0.390 & 24.20 & \\
\hline $\mathrm{O} 38 \mathrm{~b}$ & $51^{\circ} 28^{\prime} 52^{\prime \prime}$ & $4^{\circ} 11^{\prime} 15^{\prime \prime}$ & -1 & 131 & 0.270 & 7.40 & \\
\hline
\end{tabular}

were used. Diversity of the taxonomical units was measured using the Hill's diversity numbers (Hill, 1973), the evenness indices of Heip (1974) and Alatalo (1981) and the formerly used $\mathrm{H}, \mathrm{H}^{\prime}$, J and SI to allow comparison with literature. The whole set of biological data, sediment characteristics, geographic position and depth were submitted to correlation analysis using the non parametric Spearman rank correlation coefficient. Abundance, biomass and diversity of the total meiofauna, the nematodes and the copepods were analyzed either by the non parametric KruskalWallis or the parametric 1-way ANOVA (for homogenous data). A detailed list of the data are given by Smol (1986).

\section{Results}

\section{Sediment characteristics}

Sediment characteristics of the investigated stations are represented in Table 1 and the mean value of the main characteristics is plotted for the subtidal and intertidal zone and the 3 parts of the Oosterschelde in Fig. 2. 
Table 2. Mean density and biomass of the total meiofauna, the nematodes and the copepods for the subtidal and intertidal (per $10 \mathrm{~cm}^{2}$ )

\begin{tabular}{|c|c|c|c|c|c|c|}
\hline & \multicolumn{2}{|c|}{ Meiofauna } & \multicolumn{2}{|c|}{ Nematoda } & \multicolumn{2}{|c|}{ Copepoda } \\
\hline & Density & Biomass & Density & Biomass & Density & Biomass \\
\hline Subtidal & 2000 ind. & $0.9 \mathrm{~g}$ & 1600 ind. & $0.6 \mathrm{~g}$ & 303 ind. & $0.09 \mathrm{~g}$ \\
\hline Intertidal & 5400 ind. & $2.7 \mathrm{~g}$ & 5000 ind. & $2.0 \mathrm{~g}$ & 126 ind. & $0.2 \mathrm{~g}$ \\
\hline
\end{tabular}

Median grain size. The sand fraction of the sediment consisted of very fine to medium sand, the median grain size ranging between $111 \mu \mathrm{m}-$ $394 \mu \mathrm{m}$. These minimum and maximum scores were found in station 024 and 03 respectively, the latter being located outside the Oosterschelde.

The subtidal stations had a mean median grain size of $220 \mu \mathrm{m}$. Most of them were characterized by fine and medium sands. Very fine sand was restricted to station 020 only. The coarsest sedi- ments were found in the western region with a mean value of $246 \mu \mathrm{m}$. Towards the inner basin the mean value decreased, being $214 \mu \mathrm{m}$ and $117 \mu \mathrm{m}$ in the central and eastern region respectively.

In the intertidal most stations were characterized by fine sands. No medium sands were found. The overall mean is $116 \mu \mathrm{m}$, with mean values of $147 \mu \mathrm{m}$ in the western area, $148 \mu \mathrm{m}$ in the middle area and $83 \mu \mathrm{m}$ in the inner basin.
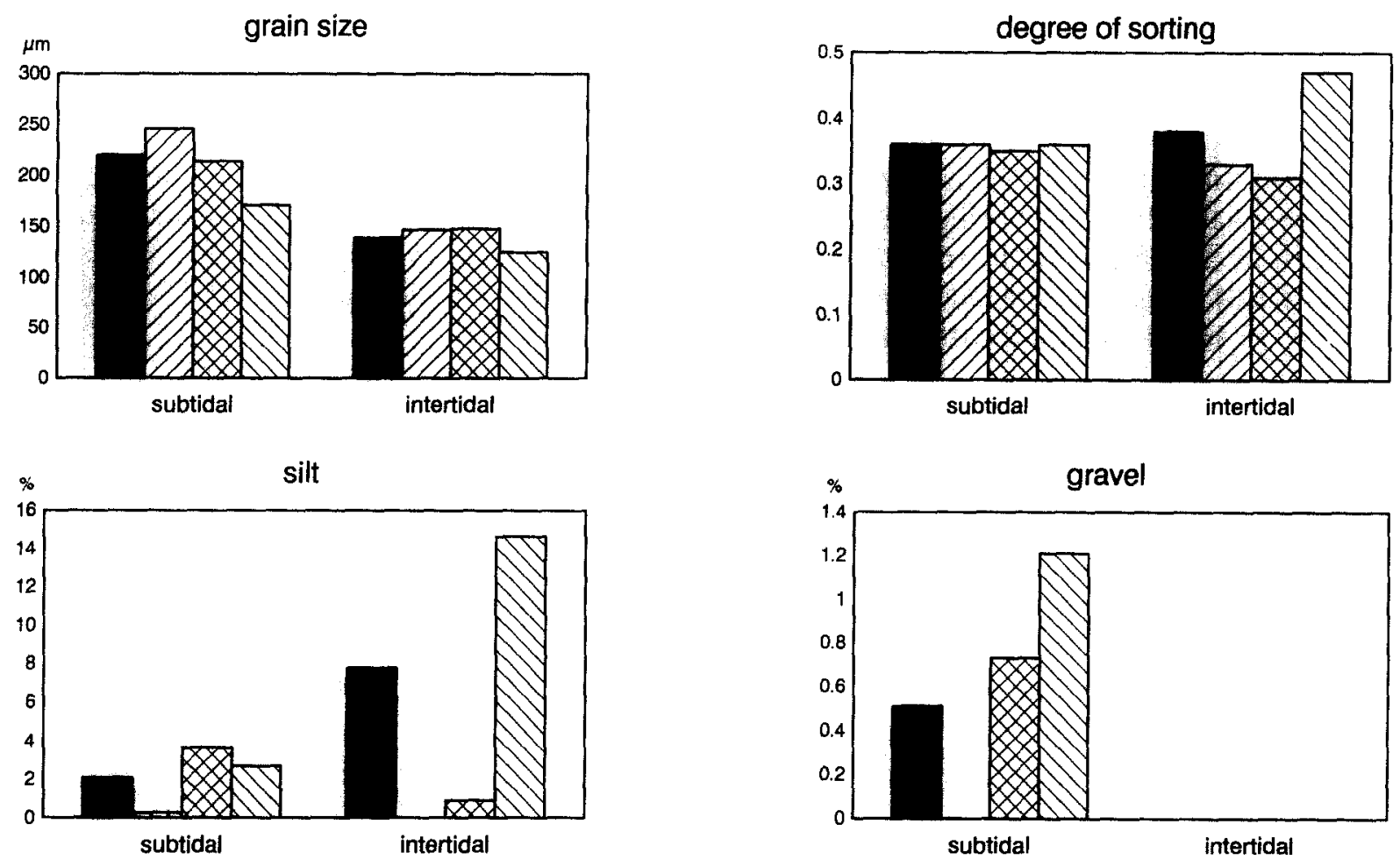

\section{$\square$ mean $\square$ west $\square$ central $\triangle$ east}

Fig. 2. Mean value of the main sediment characteristics for the subtidal and the intertidal habitat and for the 3 regions of the Oosterschelde. 
The mean median grain size of all the subtidal stations was $220 \mu \mathrm{m}$. The coarsest sediments were found in the western region: a mean value of $246 \mu \mathrm{m}$, and the finest in the eastern region: $117 \mu \mathrm{m}$; the middle region had an intermediate position: $214 \mu \mathrm{m}$.

Degree of sorting. The sediments were mostly very well $(n=15)$ or well $(n=13)$ sorted. The sorting coefficients were fairly constant throughout the Oosterschelde, except for several intertidal stations, located in the inner basin.

Silt-clay. In the subtidal most stations consisted of clean sand whereas most intertidal stations were characterized by muddy sands. Increased amounts of silt-clay were found in sheltered zones of the northern area (016), the middle region $(019$, 020) and the inner basin.

Gravel. Occasionally small amounts of gravel were found, all of it being of biogenic origin ( = shell debris).

Finally the Oosterschelde was dominated by clean, fine to medium sands which are well to very well sorted. In the shallow sheltered zones such as the inner basin the median grain size decreased paralleled by an increase of the silt-clay content.

Statistically significant differences were found between the subtidal and intertidal for both median grain size $(p<0.011)$ and silt-clay content $(p<0.002)$. However the west-east gradient could not be confirmed by statistical analysis.

The stations could be classified into following sediment types: clean fine sand, very well sorted; clean fine sand, well sorted; slightly mixed fine sand, well sorted; clean medium sand, well sorted; slightly mixed fine sand, very well sorted. All other sediment types were less important and scored less than $5 \%$ of all samples.

\section{Meiofaunal composition and abundance}

The meiobenthos community of the Oosterschelde was very diverse: 12 higher taxa were identified: Nematoda (176 species), Copepoda
Harpacticoida (97 species), Turbellaria (95 species), Ostracoda (17 species), Gastrotricha (10 species), Archiannelida (8 species), Oligochaeta, Hydrozoa (4 species), Halacarida, Tardigrada, Kinorhyncha (1 nov. species), and Rotifera ( 9 species). A species list for each taxon is provided by Smol (1986).

The meiofauna community was dominated by nematodes throughout the Oosterschelde, followed by copepods, gastrotrichs and turbellarians. Nematodes and copepods together comprised about $90 \%$ of the meiofauna (Fig. 3). The average relative abundance of the nematodes was $88 \%$ for the intertidal and $64 \%$ for the subtidal. Although copepods were ranked second, they were particularly important in the subtidal where they represented almost one fourth $(24 \%)$ of the total meiofauna density. The other taxa made up only $3 \%$ and $1 \%$ in the sub- and intertidal habitats respectively.

The density of the total meiofauna community ranged between 200 and 17500 ind $10 \mathrm{~cm}^{-2}$. On tidal flats the mean total density was much higher (5400 ind $10 \mathrm{~cm}^{-2}$ ) than in the subtidal (2000 ind $10 \mathrm{~cm}^{-2}$ ) (Fig. 4). This figure shows the overwhelming abundance of nematodes in both habitats. The copepods and gastrotrichs ranked second depending on the community. Differences between the intertidal and subtidal were significant $(p<0.002)$.

Nematode density fluctuated between 100 ind $10 \mathrm{~cm}^{-2}(012)$ and 7100 ind $10 \mathrm{~cm}^{-2}$ (037a). A mean density of 1500 ind $10 \mathrm{~cm}^{-2}$ and 5000 ind $10 \mathrm{~cm}^{-2}$ was representative for the sub- and intertidal respectively, these scores were statistically different $(p<0.002)$. In 10 out of 24 subtidal stations the importance of the nematode group was $<50 \%$ of the meiofauna, but on tidal flats they represented mostly $>90 \%$ of the meiobenthos, occasionally decreasing to $70 \%$.

An inverse trend was observed for the copepods, their relative abundance became important in subtidal stations, usually exceeding $50 \%$ of the total meiofauna, and with minimal scores $(<1 \%)$ in the intertidal.

The mean copepod density was 300 ind $10 \mathrm{~cm}^{-2}$ and 120 ind $10 \mathrm{~cm}^{-2}$ for the sub- and 

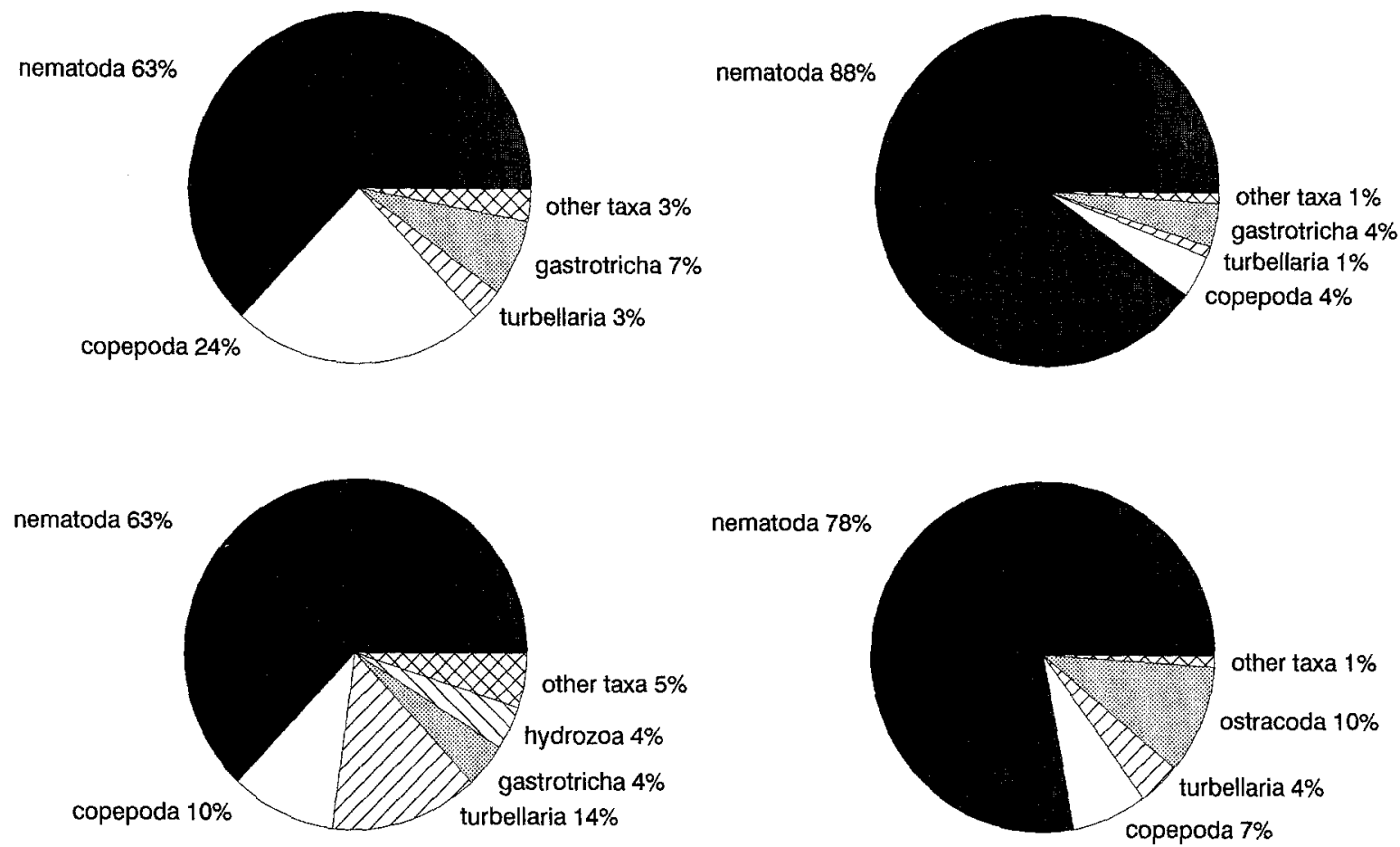

subtidal

intertidal

Fig. 3. Relative abundance (upper circles) and biomass (lower circles) partitioning of the meiofauna: comparison between subtidal and intertidal.

intertidal area respectively. No significant differences were observed. Station densities ranged between 10 ind $10 \mathrm{~cm}^{-2}(035 \mathrm{~b})$ and 1500 ind $10 \mathrm{~cm}^{-2}(015)$ with a mean density of 214 ind $10 \mathrm{~cm}^{-2}$. Only clean medium sands showed densities $>500$ ind $10 \mathrm{~cm}^{-2}$ due to the presence of interstitial fauna.

Turbellarians did occur in all but one station (absent in the intertidal 017). The population density reached a maximum of 114 ind $10 \mathrm{~cm}^{-2}(05$, situated near the storm-surge barrier). Mean densities in the sub-and the intertidal were 34 and 25 ind $10 \mathrm{~cm}^{-2}$ respectively, although this difference seemed less obvious it was significant $(p<0.000)$. The relative abundance of the turbellarians was at most $12 \%(04)$.

Gastrotrichs only occured in 20 out of 31 stations and showed great variability: $1-1100$ ind $10 \mathrm{~cm}^{-2}$. Their mean density was significantly $(p<0.000)$ higher on tidal flats $\left(288\right.$ ind $\left.10 \mathrm{~cm}^{-2}\right)$ than in the sublittoral zone (109 ind $\left.10 \mathrm{~cm}^{-2}\right)$. Their excessive numbers at particular stations resulted in a relative important ranking within the meiofauna community.

The other taxa were less important or even rare in terms of abundance although significant differences in density were observed for hydroids $(p<0.000)$ and tardigrades $(p<0.012)$, being more abundant in the subtidal and for the ostracods $(p<0.000)$ and oligochaetes $(p<0.000)$ being more abundant on tidal flats.

In Fig. 4 mean density of the most important meiofauna groups are given. From west to east mean subtidal densities of the 3 main regions showed an increasing trend for nematodes and a decreasing trend for copepods and gastrotrichs. In the intertidal an increasing trend was only found for copepods. In general the total meio- 

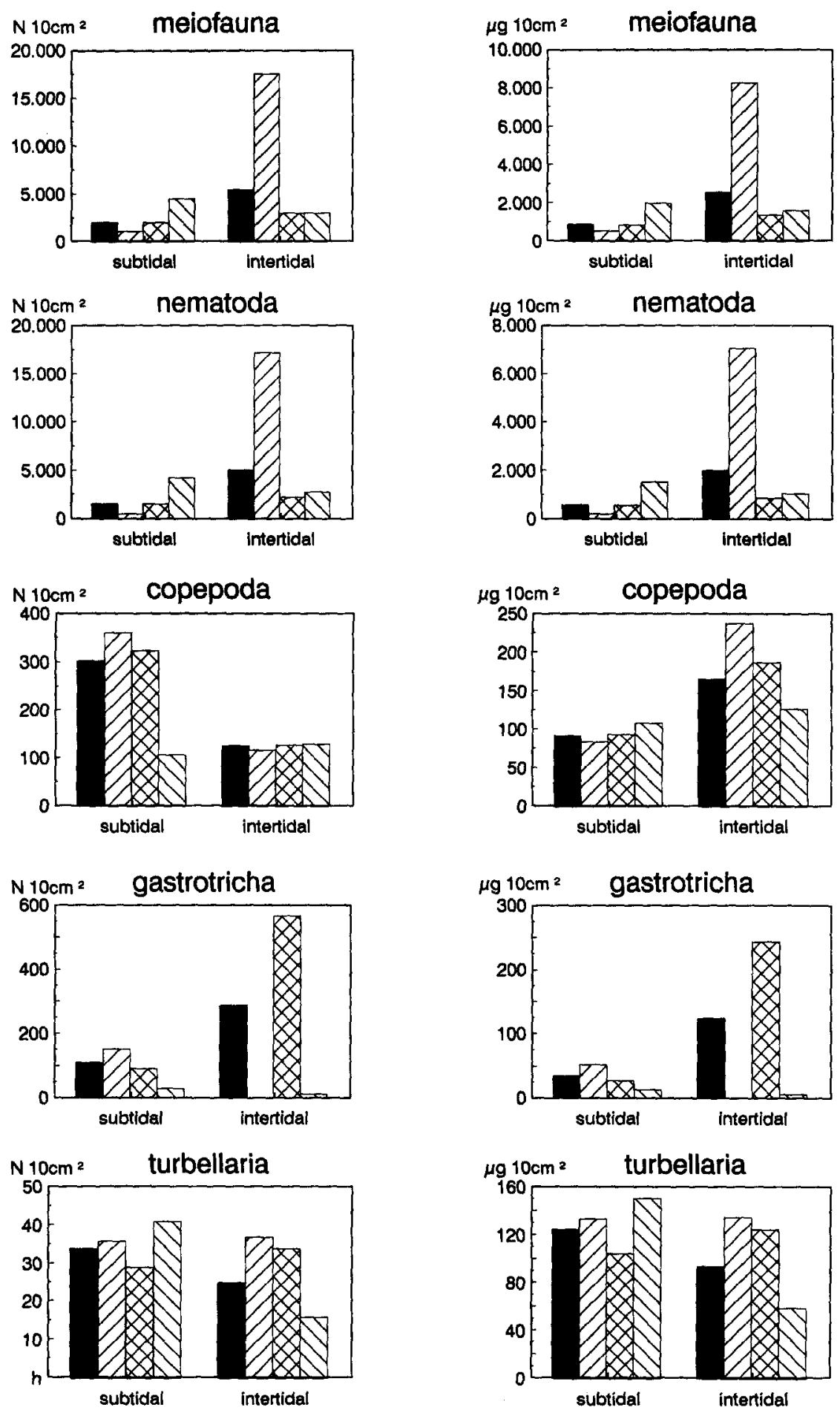

$\square$ mean $\square$ west $\bigotimes$ central $\triangle$ east

Fig. 4. Mean density (left graph) and biomass (right graph) of the meiofauna taxa: comparison between subtidal - intertidal and between the 3 main regions. 
fauna and nematode density were significantly higher in the eastern part than in the western part $(p<0.000)$.

\section{The Nematode/Copepod-ratio}

The mean nematode/copepod-ratio (N/C-ratio) per station varied between $0.3(015)$ and 184 (016); both these extreme values occurred in the sublittoral region. The mean N/C-ratio for this zone is 21.4 , whereas the mean $\mathrm{N} / \mathrm{C}$-ratio for the intertidal is 56.1 , this difference was significant $(p<0.000)$.

In the subtidal the $\mathrm{N} / \mathrm{C}$-ratio showed an increasing trend from west to east (Fig. 5), which was not found in the intertidal due to an extreme value (147) in station 037a on the Roggeplaat, located in the western region. This station was characterized by a median grain size of $147 \mu \mathrm{m}$ and $6 \%$ silt and was located at the sheltered side of the sand flat. In summer dense algal mats, diverse macrofauna species and many egg cocoons of Scoloplos armiger occurred, which made this site quite unique in offering heterogeneous micro habitats. However, the algal mats reduced the oxygen in the underlying sediment, as is noted for station $037 \mathrm{~b}$, although not affecting the N/Cratio.

\section{Biomass}

The standing stock dry weight biomass of the meiofauna community ranged between 200$8300 \mu \mathrm{g} \mathrm{dwt} 10 \mathrm{~cm}^{-2}$. Within the subtidal the biomass was increasing from west to east, but on the intertidal flats this trend was reversed (Fig. 4). A significant difference in the mean biomass between the sub- and intertidal was found, being 900 and $2600 \mu \mathrm{g} \mathrm{dwt} 10 \mathrm{~cm}^{2}$ respectively.

Mean individual dry weight of the nematodes in the Oosterschelde as determined by direct measurements was $0.38 \mu \mathrm{g}$ in summer (August). Variation in time and depth occurred (Table 3), reflecting differences in species composition and population structure. The summer values were slightly lower than those in autumn and winter,
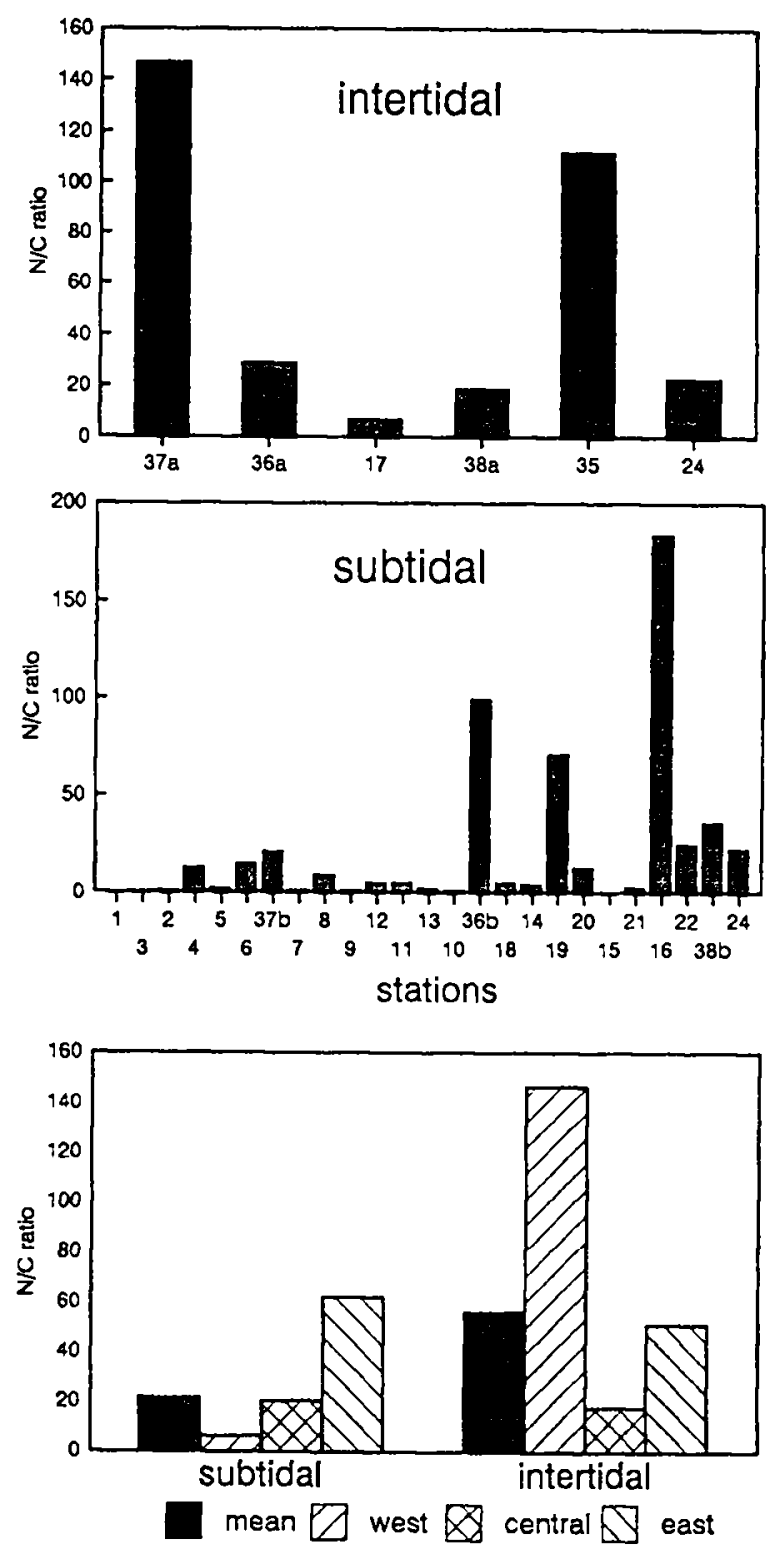

Fig. 5. The N/C-ratio per station for the subtidal and intertidal and a comparison between the mean values per habitat and region (stations are ranked from west (left) to east (right)).

probably due to an important number of juveniles. The individual dry weight of nematodes in the top $5 \mathrm{~cm}$ was about double as high as that of the nematodes in the deeper layers. Most species inhabiting the lower parts of the sediment were indeed characterized as long and thin species.

Although the overall mean individual dry weight of the nematodes $(0.38 \mu \mathrm{g})$ was about 3 
Table 3. Seasonal and depth variation of the mean individual dry weight ( $\mu \mathrm{g} \mathrm{DW}$ ind $^{-1}$ ) of nematodes and copepods (value between brackets $=$ standard error, $n=$ number of weighings).

\begin{tabular}{lllll}
\hline Time & & & & \\
\hline & May & Aug & Nov & Feb \\
\hline Nematoda & $\begin{array}{l}0.45(0.03) \\
n=45\end{array}$ & $\begin{array}{l}0.38(0.02) \\
n=14\end{array}$ & $\begin{array}{l}0.46(0.02) \\
n=11\end{array}$ & $\begin{array}{l}0.41(0.03) \\
n=11\end{array}$ \\
Copepoda & $\begin{array}{l}1.59(0.16) \\
n=17\end{array}$ & $\begin{array}{l}1.36(0.24) \\
n=9\end{array}$ & $\begin{array}{l}1.58(0.17) \\
n=7\end{array}$ & $\begin{array}{l}1.65(0.12) \\
n=3\end{array}$ \\
\hline Depth & & & & $10-15 \mathrm{~cm}$ \\
\hline & $0-5 \mathrm{~cm}$ & $5-10 \mathrm{~cm}$ & $15-20 \mathrm{~cm}$ \\
\hline Nematoda & $\begin{array}{l}0.54(0.04) \\
n=30\end{array}$ & $\begin{array}{l}0.26(0.04) \\
n=11\end{array}$ & $\begin{array}{l}0.24(0.04) \\
n=3\end{array}$ & $\begin{array}{l}0.28 \\
n=1\end{array}$ \\
\hline
\end{tabular}

times lower than that of the copepods $(1.36 \mu \mathrm{g})$, this taxon again was the dominant component of the total meiofauna biomass (Fig. 3). In the subtidal station they reached $60 \%$, followed by the turbellarians $(14 \%)$ and the copepods $(10 \%)$. Hydroids as well as gastrotrichs made up $4 \%$ each of the total biomass. On tidal flats the dominance of the nematodes was even more pronounced $(78 \%)$. Subdominant were the ostracods $(10 \%)$, followed by the copepods $(7 \%)$ and the turbellarians $(4 \%)$.

Nematode biomass per station ranged in summer between $49 \mu \mathrm{g}$ dwt $10 \mathrm{~cm}^{-2}(012)$ and $7044 \mu \mathrm{g}$ dwt $10 \mathrm{~cm}^{-2}(037 \mathrm{a})$. The subtidal environment was characterized by a mean biomass of $575 \mu \mathrm{g}$ dwt $10 \mathrm{~cm}^{-2}$ differing significantly $(p<0.000)$ from the intertidal by $1999 \mu \mathrm{g} \mathrm{dwt}$ $10 \mathrm{~cm}^{-2}$ (Fig. 4).

Copepod biomass ranged between $8.4 \mu \mathrm{g} \mathrm{dwt}$ $10 \mathrm{~cm}^{-2}(012)$ and $282.9 \mu \mathrm{g} \mathrm{dwt} 10 \mathrm{~cm}^{-2}(038 \mathrm{~b})$ per station.

The overall mean was $114.8 \mu \mathrm{g} \mathrm{dwt} 10 \mathrm{~cm}^{-2}$ with a mean value of $92 \mu \mathrm{g} \mathrm{dwt} 10 \mathrm{~cm}^{-2}$ and $166 \mu \mathrm{g} \mathrm{dwt} 10 \mathrm{~cm}^{-2}$ for the sub- and intertidal respectively, this difference was not significant. The biomass followed to a certain extend the pattern of abundance but this pattern was distorted by extreme differences in body size and thus individual dry weights of the species.
Both Paramesochridae and Cylindropsyllidae were the most abundant but as typical interstitial types their importance was strongly reduced as far as biomass goes. The same held for the mesopsammic component of the fauna. This was explained by the fact that these families only consisted of mesopsammic species i.e. small, vermiform copepods with an extremely low individual dry weight (range: $0.1-0.5 \mu \mathrm{g}^{-1} \mathrm{~d}^{-1}$ ).

Except for the Ectinosomatidae, the other families showed a reverse trend, since many members had a relatively high individual dry weight (range: $2-5 \mu \mathrm{g}^{-1}$ ind $^{-1}$ ). Thus, many more families shared dominance. Among the ecological groups only the psammophilous and euryoecious faunas were of any importance. Dominance in biomass was evenly shared by the mesopsammic, epi-endopsammic and euryoecious species.

Turbellarian total biomass ranged between

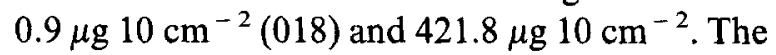
mean value of $125 \mu \mathrm{g} 10 \mathrm{~cm}^{-2}$ for the subtidal stations was somewhat higher than that of the intertidal: $94 \mu \mathrm{g} 10 \mathrm{~cm}^{-2}$, which made them subtidally more important in terms of energy flux than the copepods (Fig. 3). However it must be reminded that turbellarians are predators and one cannot compare their importance in the system on the basis of weight alone.

The total biomass of the gastrotrichs varied between $0.4 \mu \mathrm{g} 10 \mathrm{~cm}^{-2}(016)$ and $488.4 \mu \mathrm{g}$ $10 \mathrm{~cm}^{-2}(036 \mathrm{a})$. High biomass values for the other taxa were noted in station 014: $303 \mu \mathrm{g}$ $10 \mathrm{~cm}^{-2}$ (hydroids), 06: $135 \mu \mathrm{g} 10 \mathrm{~cm}^{-2}$ (hydroids), 038b: $196 \mu \mathrm{g} 10 \mathrm{~cm}^{-2}$ (polychaetes). On the tidal flats ostracods became an important component of the biomass: $360 \mu \mathrm{g} 10 \mathrm{~cm}^{-2}(017)$, $140 \mu \mathrm{g} 10 \mathrm{~cm}^{-2}(035), 636 \mu \mathrm{g} 10 \mathrm{~cm}^{-2}(037 \mathrm{a})$

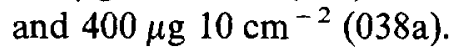

\section{Variation in time and space}

\section{Vertical distribution}

The depth distribution of the meiofauna according to the geographic location is given in Fig. 6, both for the intertidal and subtidal environment ( $-1 \mathrm{~mm}$ below low water level and $>10 \mathrm{~m}$ deep). 

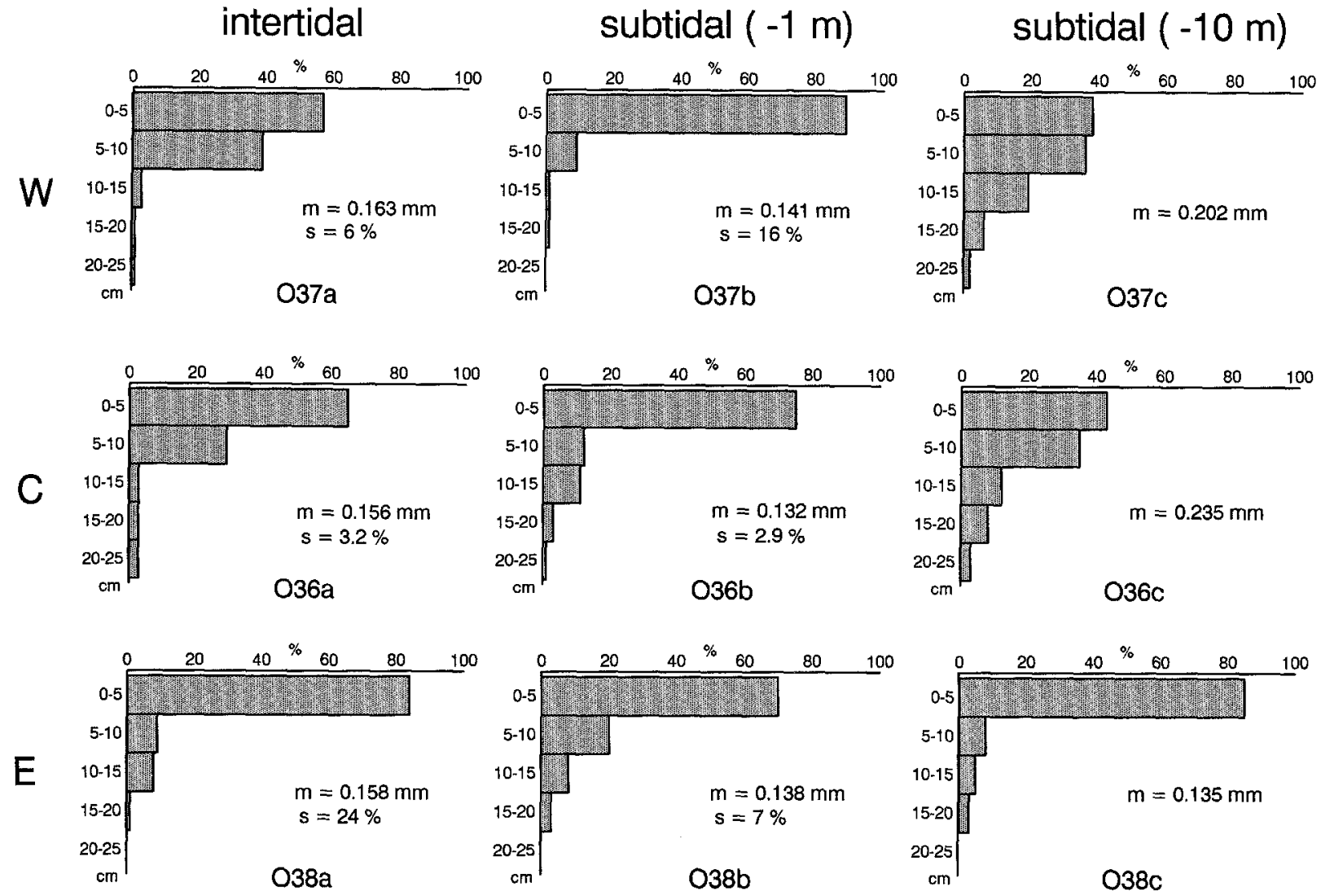

Fig. 6. Vertical distribution of the meiofauna according to the geographic location: 9 stations distributed over the subtidal and intertidal habitat and the 3 regions $(\mathrm{W}=$ west; $\mathrm{C}=$ central; $\mathrm{E}=$ east) of the Oosterschelde $(\mathrm{m}=$ median grain size, $s=$ silt-clay fraction).

Meiofauna occurred to a depth of $25 \mathrm{~cm}$ (maximum sampling depth) into the sediment. In all stations the bulk of the meiofauna $(>70 \%)$ inhabited the upper $10 \mathrm{~cm}$, on tidal flats more than $90 \%$ were restricted to that layer. Towards the east the decreasing median grain size superimposed by an increasing silt-clay content resulted in a concentration of more than $80 \%$ of the meiofauna in the top $5 \mathrm{~cm}$ of the sediment. This clearly reflected a response of the meiofauna to two main sediment characteristics i.e. the amount of siltclay and the median grain size.

\section{Seasonal changes: Fig. 7}

A pronounced seasonality was found to exist for most meiofauna groups, generally with a maximum abundance in the warm seasons and a minimum in winter. Highest total meiofauna densities were observed in summer: 18000 ind $10 \mathrm{~cm}^{-2}$ (037a) and lowest in winter: 744 ind $10 \mathrm{~cm}^{-2}$ (037b).

Nematodes, being the dominant taxon, fluctuated according to the same pattern. In the intertidal the density sometimes increased up to 20 times the winter values (037a).

In the western part the density of the nematodes at the subtidal station was lower in summer than in spring. The presence of dark granules in the intestine of more than $50 \%$ of the nematodes indicated a detoxification system for sulphide ions (and oxygen depletion, cfr. Nuss, 1984). This was confirmed by a strong $\mathrm{H}_{2} \mathrm{~S}$-smell. Most probably this $\mathrm{H}_{2} \mathrm{~S}$-stress had its repercussion on the density of the nematodes, the copepods and other groups.

The copepod population reached its highest 
DENSITY
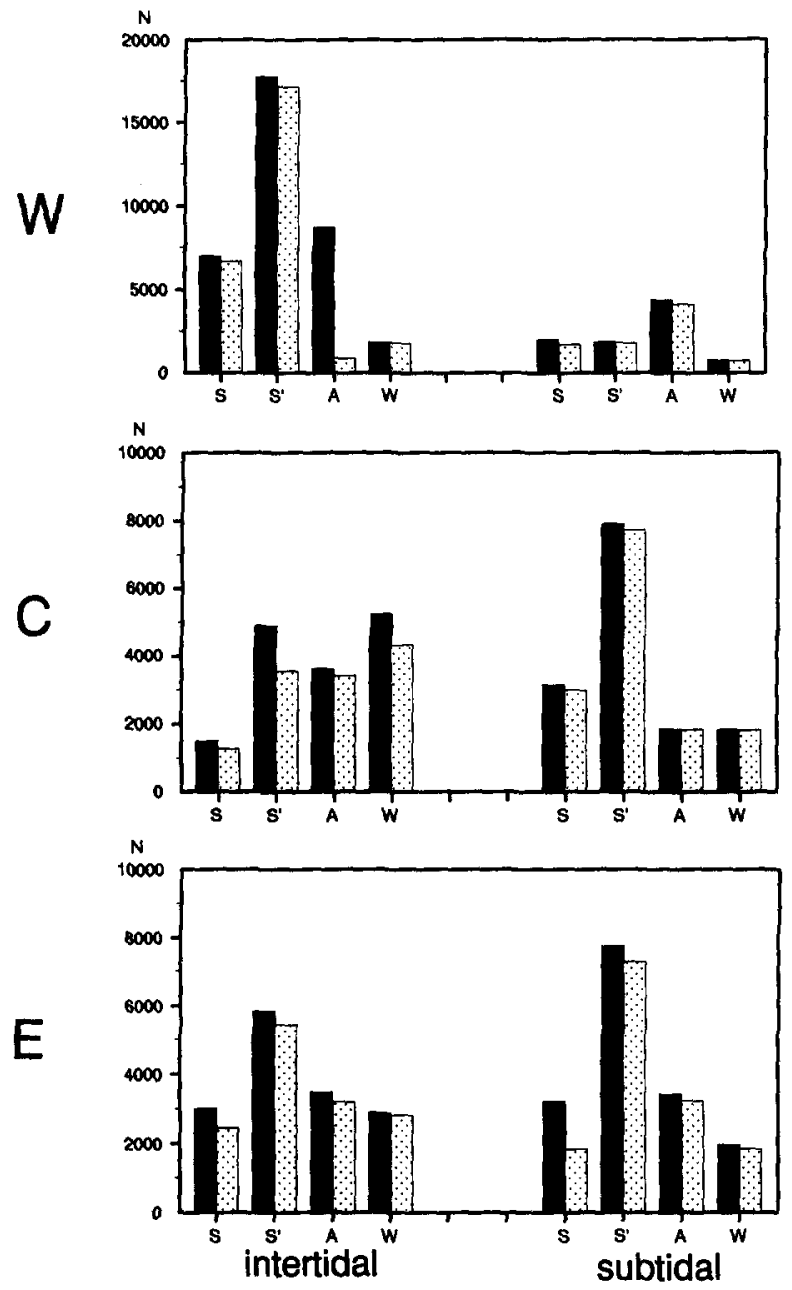

BIOMASS
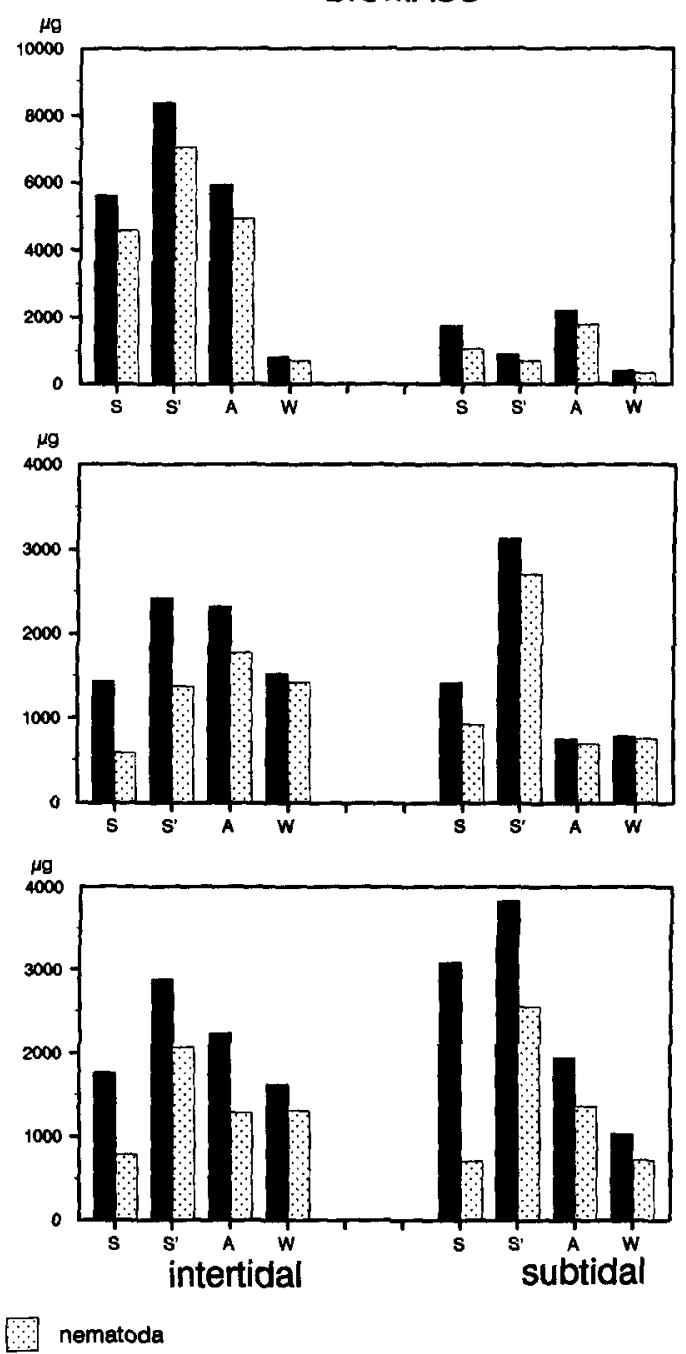

Fig. $7 a$.

density in spring at the subtidal station $038 \mathrm{~b}$. The stations situated in the western and central part had a peak in autumn and in summer respectively. A peak abundance for the turbellarians, the ostracods and the tardigrades was noted either in spring, summer or autumn; their minimum was always observed in winter.

The total biomass of the meiofauna was highest in summer with values of $8.4 \mathrm{mg} 10 \mathrm{~cm}^{-2}$

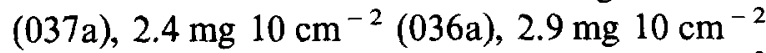
(038a) for the intertidal and $2.21 \mathrm{mg} 10 \mathrm{~cm}^{-2}$ (037b), $3.1 \mathrm{mg} 10 \mathrm{~cm}^{-2}$ (036b), $3.8 \mathrm{mg} 10 \mathrm{~cm}^{-2}$ (038b) for the subtidal. The seasonal pattern was most pronounced in station $037 \mathrm{a}$, the summer value being 10 times higher than in winter, due to the dramatic increase in numbers $(x 20)$ and in biomass $(\times 10)$ of the nematodes. The variation of the biomass of the nematode population was in accordance with the fluctuations in density. Minimum biomass values for the copepods as well as for the other groups were observed in winter and maximum peaks occurred in the other seasons, often reaching 15 times the winter values.

The abundance and biomass of the ostracods sometimes exceeded that of the turbellarians and 

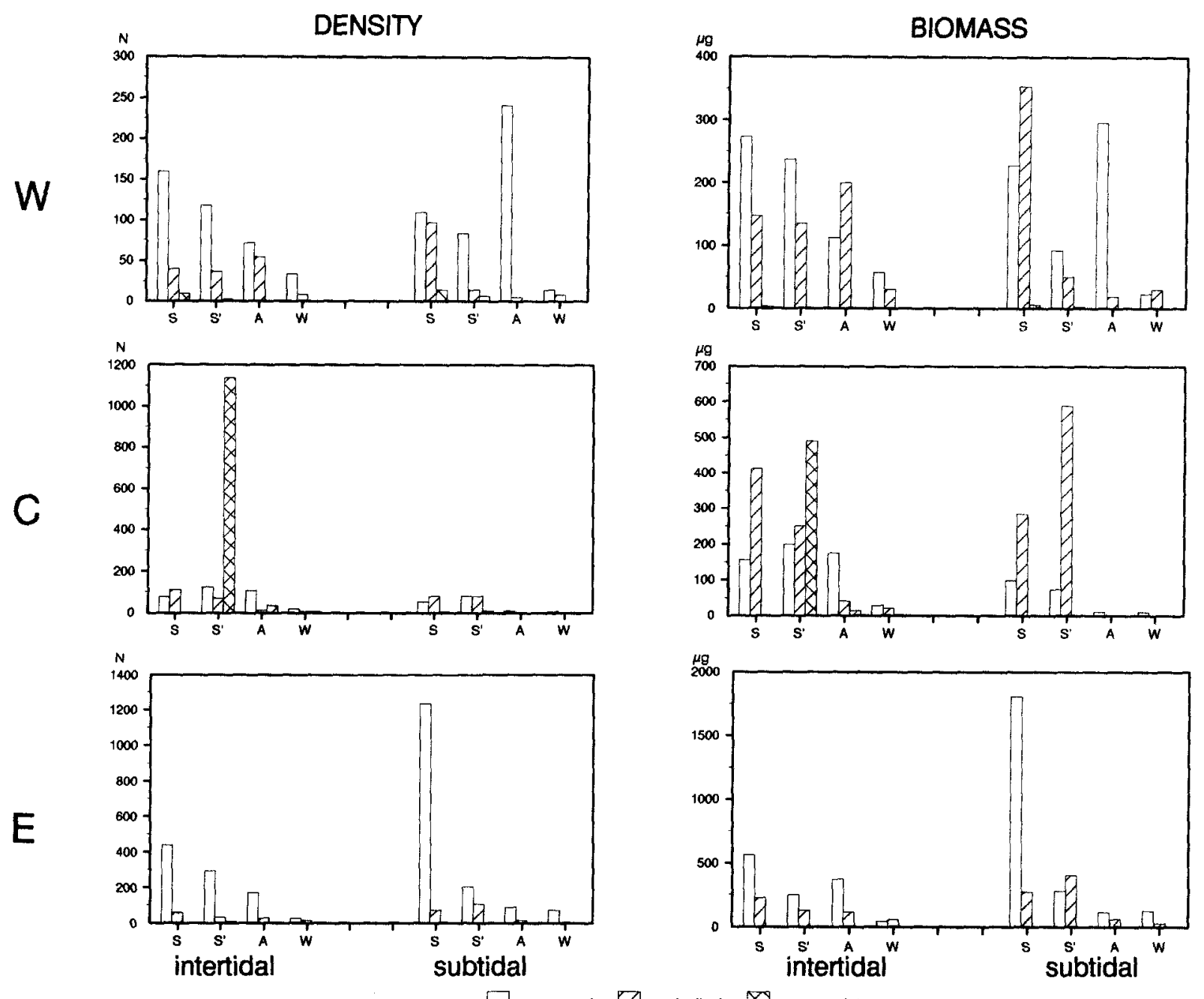

copepoda $\square$ turbellaria gestrotricha

Fig. $7 b$.

in the central region the biomass of the latter exceeded that of the copepods in spring and summer.

\section{Diversity}

The number of meiofauna taxa was lowest in station 017: 4 and highest in 037a and 038b: 11 taxa (Fig. 8). One could expect a mean of 7 taxa in the subtidal stations and a mean of 8 on the tidal flats, although the mean diversity measured by the set of indices as indicated in Table 4 was higher in the subtidal stations than in the intertidal stations.
The number of nematode species varied between 20 and 33 per station. In the intertidal there was a clear increase in number of species from west to east and the diversity and evenness were higher intertidally than subtidally.

The species richness of the copepod community varied between $6-21$ species per station. The highest scores were found in subtidal clean medium sands and subtidal muddy fine sands of the outer area and the inner basin respectively. The lowest number of species was observed in clean fine sands in the intertidal zone of the middle area.

A mean of 9 and 7 species was calculated for 

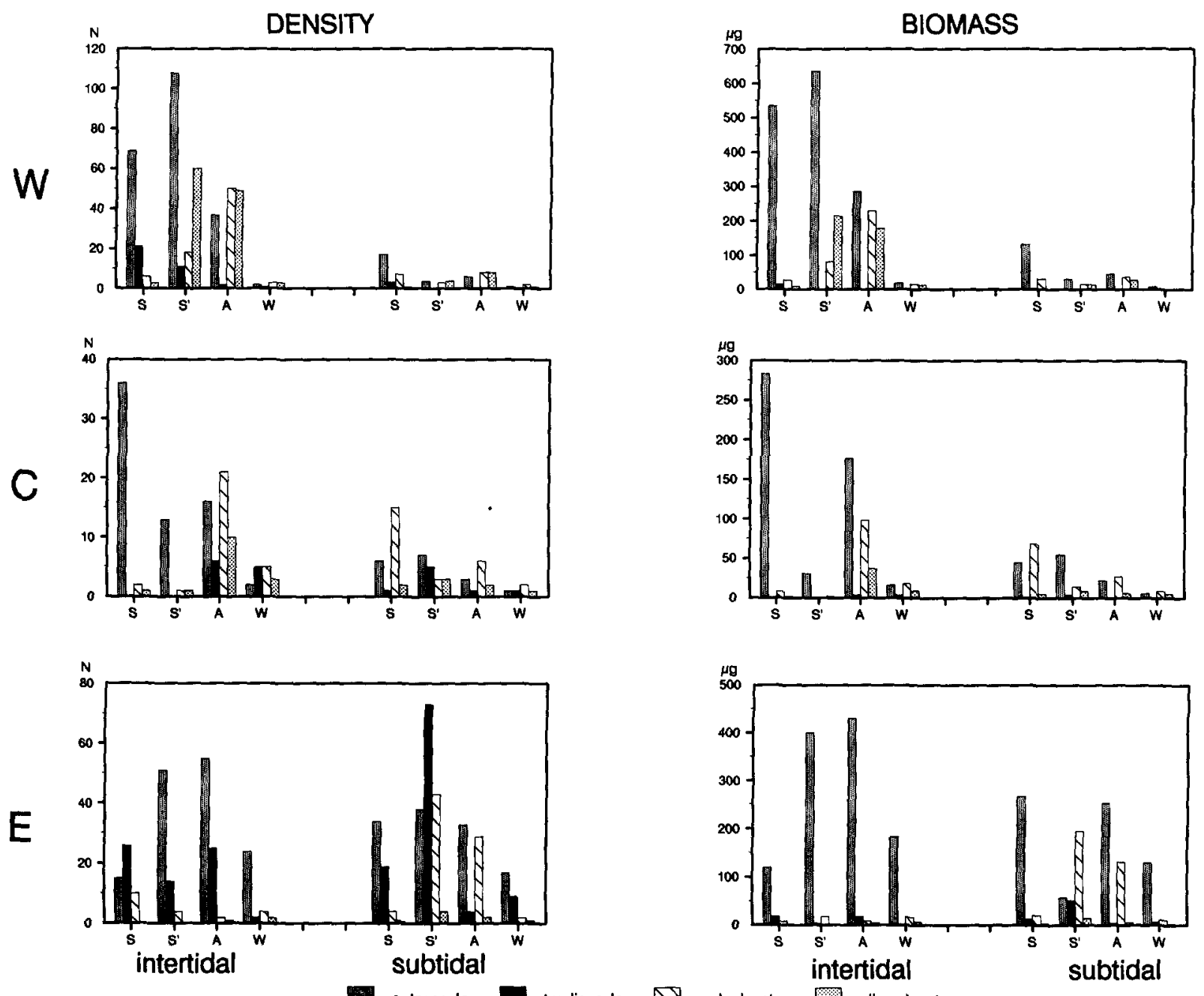

Fig. $7 c$.

Fig. 7. Seasonal changes in density (ind $\left.10 \mathrm{~cm}^{-2}\right)$ and biomass $\left(\mu \mathrm{g}\right.$ DW $\left.10 \mathrm{~cm}^{-2}\right)$ of the meiofauna taxa $\left(\mathrm{S}=\right.$ spring; $\mathrm{S}^{\prime}=$ summer; $\mathrm{A}=$ autumn; $\mathrm{W}=$ winter; $\mathrm{W}=$ west; $\mathrm{C}=$ central; $\mathrm{E}=$ east ).

7a: Total meiofauna and Nematoda

7b: Copepoda, Turbellaria, Gastrotricha

7c: Ostracoda, Tardigrada, Polychaeta, Oligochaeta

subtidal and intertidal respectively. For each of the diversity indices the copepod community was more diverse in the subtidal than in the intertidal.

Comparing the diversity of the copepods between the subtidal-intertidal stations on the one hand and the 3 main regions of the Oosterschelde on the other hand, significant differences for different indices were observed as shown in Table 4.
In both cases the number of species was significantly different. The discrepancy between the suband intertidal was mainly caused by differences in evenness (or abundance) of the species and the difference between the western and eastern region of the Oosterschelde was mainly due to the diversity (or number of species). A classical 1-way ANOVA had the same results. 

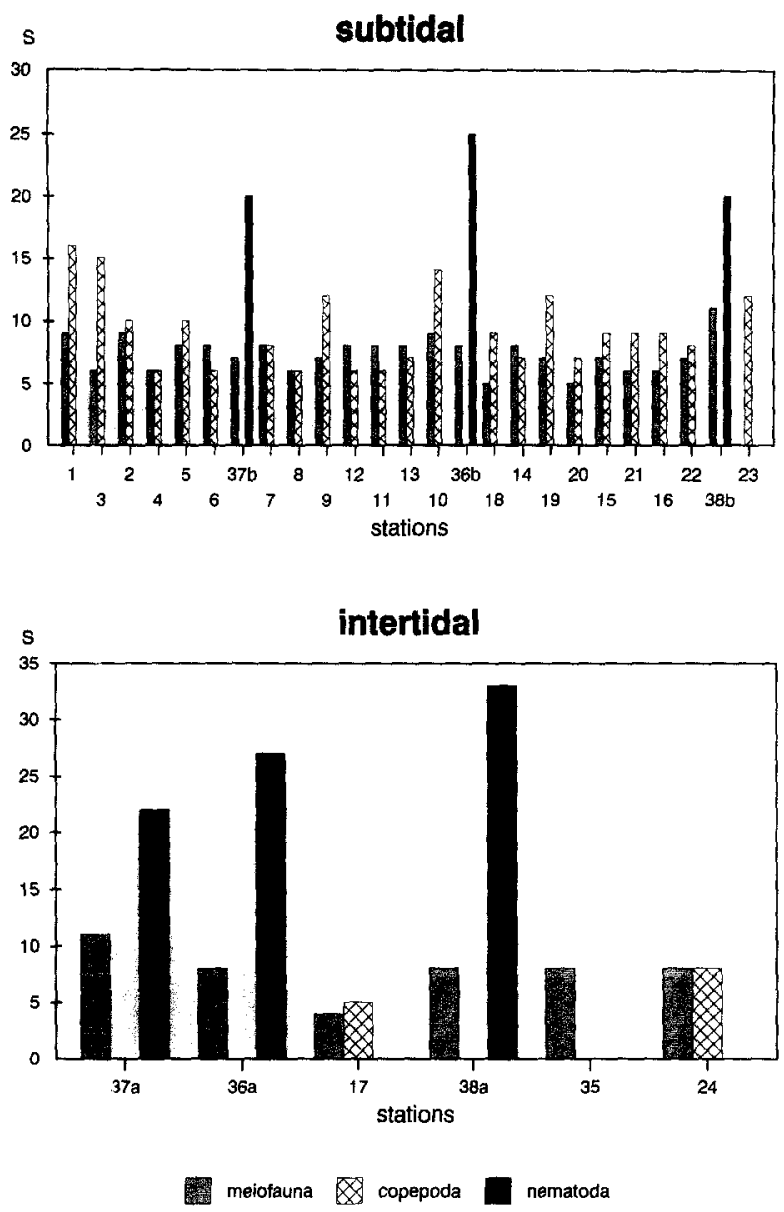

Fig. 8. Number of meiofauna taxa, and number of nematode and copepod species per station (stations ranked from west (left) to east (right).

\section{Nematode community}

A total of 176 species belonging to 97 genera and 20 families were identified. The number of species per station ranged between 15 to 48 . Dominant families $(\geq 10 \%)$ were in descending order $\mathrm{Xy}$ alidae, Comesomatidae, Oncholaimidae, Desmodoridae, Axonolaimidae, Enoplidae and Chromadoridae.

The subtidal stations were dominated by Daptonema riemanni, Sabatieria vulgaris, $S$. breviseta, Viscosia viscosa, Enoplolaimus propinquus, Ascolaimus elongatus, Daptonema fallax, and Metadesmolaimus varians.

The tidal flats were mainly occupied by Metachromadora vivipara, Spirinia parasitifera,
Table 4. Diversity of the meiofauna, the nematodes and the copepods: comparison of the diversity of the copepods between subtidal-intertidal ( = habitat) and between the 3 regions of the oosterschelde (= area); probabilities of the Kruskall-Wallis analysis are given $\left(\mathrm{H}^{\prime}=\right.$ Shannon-Wienerindex, $\mathbf{H}=$ Brillouin-index, $\mathbf{S I}=$ Simpson-index, $\mathbf{J}=$ Pielou's index, N1, N2, E1,0, E2,1 = Hill's numbers, E'1,0= Heipindex, $E^{\prime} 2,1=$ Alatalo-index, $N \propto=$ dominance index).

\begin{tabular}{lll}
\hline & Habitat & Area \\
\hline $\mathrm{H}^{\prime}$ & 0.650 & $0.006^{* *}$ \\
$\mathrm{H}$ & 0.750 & $0.008^{* *}$ \\
$\mathrm{SI}$ & 0.391 & $0.03^{*}$ \\
$\mathrm{~J}$ & $0.001^{* * *}$ & 0.169 \\
$\mathrm{~N} 1$ & 0.545 & $0.007^{* *}$ \\
$\mathrm{~N} 2$ & 0.356 & $0.032^{*}$ \\
$\mathrm{E} 1,0$ & $0.000^{* * *}$ & 0.334 \\
$\mathrm{E}^{\prime} 1,0$ & $0.001^{* *}$ & 0.249 \\
$\mathrm{E} 2,1$ & $0.099^{\prime}$ & 0.359 \\
$\mathrm{E}^{\prime} 2,1$ & $0.039^{*}$ & 0.609 \\
$\mathrm{~S}$ & $0.021^{*}$ & $0.048^{*}$ \\
$\mathrm{~N} \propto$ & $0.237^{*}$ & 0.362 \\
\hline
\end{tabular}

Oncholaimellus sp., Sabatieria vulgaris, Ascolaimus elongatus, Daptonema riemanni.

Particularly the genera Sabatieria and Daptonema were represented by several species.

Among the ecological feeding groups the nematode community was dominated in terms of abundance by non-selective deposit feeders. The predators/omnivores ranked second, followed by the epistratum feeders and the selective deposit feeders.

\section{Copepod community}

A total of 1 cyclopoid and 70 harpacticoid copepod species were found, the latter belonging to 14 families and 47 genera.

Seven families represented 56 species $(78.8 \%)$; these were in order of their importance: Ectinosomatidae, Diosaccidae, Laophontidae, Cylindropsyllidae, Cletodidae, Tachidiidae and Paramesochridae. Only 2 species could be characterized as very common ( $>50 \%$ ) based on their occurrence in the total data-set: Asellopsis intermedia and Harpacticus flexus. Twenty species were common $(25-49 \%)$; these were in order of 
their frequency: Pseudobradya beduina, Tachidius discipes, Euterpina acutifrons, Arenosetella tenuissima, Canuella perplexa, Paraleptastacus espinulatus, Enhydrosoma propinquum, Pseudobradya minor, Evansula pygmaea, Klyopsillus constrictus s.str., Halectinosoma herdmani, Leptastacus laticaudatus, Kliopsyllus paraholsaticus, Canuella furcigera, Arenosetella germanica, Arenocaris bifida, Paronychocamptus nanus, $P$. curticaudatus, Stenhelia palustris, Halectinosoma gothiceps. Rare (5$24 \%)$ and very rare $(<5 \%)$ species constituted together 49 species ( 23 and 26 respectively).

In terms of their relative abundance the family Paramesochridae strongly dominated. Sub-dominance was shared between the Cylindropsillidae and Ectinosomatidae. The dominance of the Paramesochridae and Cylindropsillidae was reflected in the dominance of the psammophilous, particularly the mesopsammic species. Only the epi-endopsammic and euryoecious groups were subdominant and of equal importance.

Among the ecological groups only psammophilous and euryoecious groups were of any importance followed by the limicolous and phytophilous groups.

The groups of psammophilous and euryoecious species together comprised 51 species, $71.9 \%$ of the total number. Twenty of these species accounted for $91.0 \%$ of the very common and common species groups. Within the psammophilous fauna 20 species $(62.5 \%)$ were mesopsammic, 8 of which made up $36.4 \%$ of the very common and common species. Epi-endopsammon (6 species) and euryoecious ( 6 species) each accounted for $27.3 \%$.

\section{Turbellarian community}

The density of the turbellarians and their species diversity was much higher in the Oosterschelde than in lake Grevelingen or in the Westerschelde (Martens \& Schockaert, 1981). The same authors found that in the Delta as a whole, Proseriata and Acoela were about equally well represented and approximately one fifth of the turbellarian fauna consisted of Neorhabdocoela and $90 \%$ of these were Kalyptorhynchia.
A list of species determined at the stations 013 and 018 in 1979 is represented in Martens and Schockaert (1981).

\section{Abundance and environmental parameters}

In the Oosterschelde the variation in space of meiofaunal abundance was significantly correlated with environmental parameters such as: median grain size of the sand fraction, amount of silt-clay, amount of gravel, sorting, depth, and longitude. Significant correlation coefficients are presented in Table $5\left(p<0.01\right.$ for $\left.n=29, r_{s}=463\right)$.

The density and relative abundance of the nematodes and to a lesser extent the density of the ostracods and oligochaetes increased significantly with decreasing median grain size and increasing silt content.

Turbellarian density increased with a higher degree of sorting and the same holds for the tardigrades.

The number of gastrotrichs was negatively correlated with the silt content and their importance in the meiofauna composition responded to a coarser sand and lesser mud.

Highest hydroid abundance was found in the clean coarser sands, their numbers decreasing to the east.

For the copepods only the relative importance was highly significant being positively correlated with the median grain size and negatively with the silt-clay fraction.

The N/C-ratio exhibited a similar correlation with grain size and silt-clay content as the nematodes and increased with increasing sorting and decreased with depth.

The relative abundance of nematodes was significantly correlated with longitude, becoming more important to the east. Both the percentage of nematodes and oligochaetes increased with increasing silt-clay content and decreasing median grain size and depth.

Copepods, turbellarians, gastrotrichs and hydroids became more important with increasing median grain size and decreasing silt-clay content.

Among the environmental factors the median 
Table 5. Significant correlations $(p<0.001)$ between different biotic and abiotic parameters: Spearman rank correlation coefficients.

\begin{tabular}{|c|c|c|c|c|c|c|}
\hline & Grain size & Sorting & Silt-clay & Gravel & Depth & Longitude \\
\hline Density meiofauna & -0.609 & & 0.534 & & -0.486 & \\
\hline Density nematoda & -0.824 & & 0.704 & & -0.629 & \\
\hline Density turbellaria & & -0.554 & & & & \\
\hline Densily gastrotricha & & & -0.496 & & & \\
\hline Densily tardigrada & & -0.492 & & & & \\
\hline Density ostracoda & -0.574 & & 0.527 & -0.538 & -0.691 & \\
\hline Density hydrozoa & 0.678 & & -0.721 & & 0.647 & -0.472 \\
\hline Density oligochaeta & -0.617 & & 0.592 & & & \\
\hline N/C-ratio & -0.824 & -0.049 & 0.823 & & -0.575 & \\
\hline$\%$ nematoda & -0.837 & & 0.845 & & -0.589 & 0.476 \\
\hline$\%$ copepoda & 0.809 & & -0.792 & 0.548 & & \\
\hline$\%$ turbellaria & 0.587 & & -0.644 & & 0.661 & \\
\hline$\%$ gastrotricha & 0.544 & & -0.566 & & 0.491 & \\
\hline$\%$ ostracoda & & & & -0.528 & -0.628 & \\
\hline$\%$ hydrozoa & 0.759 & & -0.733 & & 0.718 & -0.475 \\
\hline$\%$ polychaeta & & & & & 0.540 & \\
\hline$\%$ oligochaeta & -0.533 & & 0.527 & & & \\
\hline Biomass meiofauna & -0.657 & & 0.505 & & -0.522 & \\
\hline Biomass nematoda & -0.817 & & 0.700 & & -0.635 & \\
\hline Biomasis copepoda & & & & & -0.509 & \\
\hline Biomas s ostracoda & -0.576 & & 0.540 & -0.529 & -0.655 & \\
\hline Biomass turbellaria & & -0.549 & & & & \\
\hline Diversity taxa & 0.700 & & -0.700 & & 0.600 & \\
\hline Depth & 0.651 & & & & & \\
\hline Longitude & -0.495 & & 0.483 & & & \\
\hline Silt-clay & -0.844 & & & & & \\
\hline
\end{tabular}

grain size showed a positive relation with depth and a negative relation with longitude and siltclay content, the latter increasing from west to east and decreasing with depth.

The diversity of the meiofauna community increased in coarser sand and lower amount of siltclay and is positively correlated with depth (below approximately known sea level). No relation was detected between the diversity of the copepods and the sediment characteristics.

\section{Discussion}

The Oosterschelde was strongly influenced by tidal currents causing a heterogeneous and unstable biotope characterized by environmental gradients. Especially the tidal flats were daily subjected to greater fluctuations of temperature and salinity, and different faunal assemblages in the subtidal and intertidal habitat are therefore expected.

The sediment composition, was primarily determined by the hydrodynamical forces and offered a variety of different biotopes within the Oosterschelde.

The meiofauna was very diverse with 12 permanent meiofauna taxa. In the nearby Westerschelde Van Damme et al. (1980) recorded 10 taxa in subtidal transects. In the Dutch Wadden Sea only 4 and 5 taxa were noted by Witte \& Zijlstra (1984) and Bouwman (1981) respectively, but not all meiofauna groups were taken into account.

The abundance of the meiofauna was very high in both sub- and intertidal habitats, which was partly due to the sampling season (summer). Similar high densities in subtidal areas were observed by Faubel et al. (1983) in the Fladen 
Ground, Bodin (1984) in the bay of Douarnenez, Herman et al. (1984) in the Belgian coastal zone, Ansari et al. (1980) in Goa, India; and in tidal areas by Ellison (1984) in Plymouth and Dye (1983) in South Africa.

Meiofauna abundance on the tidal flats of the Wadden Sea and the Westerschelde was generally lower.

The subtidal abundance and biomass were considerably lower and were consistent with the density of the subtidal populations in the North Sea (Heip et al., 1979), of the fine sand populations in the Bay of Morlaix, France (Boucher, 1980) and of Firemore Bay, Scotland (McIntyre \& Murison, 1973).

In the Oosterschelde nematode abundance and biomass differed significantly between the subtidal and intertidal. No such difference was noted in the literature, since all studies are restricted to one of these habitats only.

On the tidal flats nematodes predominated as in most estuaries. The observed abundance and standing stock were high and similar to those of the salt marsh Saaftinghe in the Westerschelde estuary (Van Damme et al., 1980), of the Lynher estuary (Warwick \& Price, 1979), estuaries of Georgia, USA (Teal \& Wieser, 1966) and the Eems estuary, although nematode density was slightly lower there $\left(40-10000\right.$ ind $10 \mathrm{~cm}^{-2}$, Bouwman, 1983). These high scores are typical for intertidal muddy sands.

Contradictory to our data very high numbers of copepods were found in other intertidal environments e.g. at the Galapagos a peak value of 6000 ind $10 \mathrm{~cm}^{-2}$ (Schmidt, 1978) and of 3400 ind $10 \mathrm{~cm}^{-2}$ at South Africa (McLachlan, 1977).

The number of turbellarians were in good agreement with those observed by McIntyre (1968) for an Indian estuary, but were lower than the values presented by Reise (1983) for a sandflat in Sylt and by McIntyre \& Murison (1973) for a sublittoral habitat in Firemore Bay, Scotland.

From these data it is obvious that the N/Cratio as a monitor of pollution has to be used with precaution. Within the unpolluted Oosterschelde the $\mathrm{N} / \mathrm{C}$-ratio exhibited an important variation and reached peak values (184), which according to Raffaelli \& Mason (1981) are characteristic for polluted situations. In the Oosterschelde the $\mathrm{N} / \mathrm{C}$-ratio rather reflected more the sediment characteristics as was demonstrated by its correlation with median grain size and silt-clay fraction. This implies that the use of the N/C-ratio in monitoring pollution is only valid when comparing similar sediment types, if having any value at all. This was well illustrated by station $037 \mathrm{a}$, where extremely high values of nematodes distorted the N/C-ratio without any obvious relation to perturbation. Furthermore as a ratio it is very sensitive to the aggregated pattern of both its constituent elements i.e. copepods and nematodes. One could expect large variation in the N/C-ratio as both the nematode and copepod populations displayed an aggregated distribution pattern.

In temperate regions intertidal and shallow subtidal meiobenthos are known to vary seasonally. In the Oosterschelde all taxa reached maximum abundance and biomass in the warmer months of the year. Whereas peak values occurred in spring, summer or autumn, according to the taxa, minimum scores were consistently found in winter. A similar seasonal pattern was observed by Little (1986), who noted maxima for the tardigrades, ostracods and some oligochaetes in spring.

In the intertidal of the Oosterschelde seasonality was more pronounced, which could be explained by the response of the meiofauna community to increased temperature (Heip \& Smol, 1976).

The nematode community closely resembled that of other north-west European estuaries. At the genus level resemblance was very close with the Lynher estuary (Warwick \& Price, 1979 and the Eems-Dollard (Bouwman, 1983). Although to species level the similarity was only half. Differences in microhabitat, biological interactions, food supply, structural heterogeneity of the sediment caused by macrofauna, predation etc. determined the species composition and the peculiarity of each estuary.

Although sorting has been suggested by Jansson (1967) as a relevant factor to the distribution of the meiofauna, in the Oosterschelde grain size 
was the primary factor controlling the meiofauna abundance pattern (next to temperature). Only the abundance of turbellarians and tardigrades responded positively to a higher degree of sorting.

Among the meiofauna taxa, the distribution of nematodes, gastrotrichs and oligochaetes demonstrated a similar affinity to high silt content and small particle size, nematodes scoring the best.

Interstitial groups e.g. gastrotrichs, tardigrades and hydroids prefered clean sand with coarser grain size.

\section{Conclusions}

It is clear that in the Oosterschelde both the grain size and the silt content were co-controlling the distribution and diversity of the meiofauna. Consequently, changes in tidal amplitude and current velocity enhanced by the storm-surge barrier, will alter the distribution and accumulation of the sediment particles. Clean sands will be most affected. As a result meiofauna will become more important in terms of abundance and biomass, mainly due to increasing numbers of nematodes. One can predict a general decrease in meiofauna diversity.

The number of copepods is expected to decrease and interstitial species will be replaced by burrowing and epibenthic species. The latter are more important in terms of biomass and thus as food for the epibenthos. Among the meiofauna taxa, differences in activity and availability result in harpacticoids as the preferred food for the epibenthos, with ostracods making up the rest (Pihl, 1985; Gee, 1987). This is more evident in muddy intertidal sediments, where almost the total population of the prey species is concentrated in the top $3 \mathrm{~mm}$ (Gee, 1987).

Recently it has been shown that epibenthic crustacea, particular shrimps (Crangon crangon), are the most important epibenthic consumers of meiofauna from intertidal and shallow subtidal habitats (review in Hicks \& Coull, 1983; Pihl, 1985; Gee, 1987). According to Hostens \& Hamerlynck (1993) in the Oosterschelde Crangon crangon belongs to the top 5 epibenthos species in terms of density as well as biomass. The crab Carcinus maenas, also a dominant species in the Oosterschelde is known to feed on meiofauna (Sherer \& Reise, 1981). Gee (1989) reviewed the importance of fish as predators on meiofauna taxa, and notes that flatfish and gobies appear to be the main groups of fish feeding on meiofauna; the former dominating in sandy habitats and the latter being more prevalent in muddy habitats. In the Oosterschelde flatish such as Pleuronectes platessa, Limanda limanda and the goby Pomatoschistus minutus score within the top 5 dominant epibenthic species. Both flatfishes also dominate the biomass of the epibenthos (Hostens \& Hamerlynck, 1993). An increase in the numbers of nematodes will increase bioturbation (Cullen, 1973), nutrient remineralization (Warwick \& Price, 1979, Platt \& Warwick, 1980) and sustain bacterial growth (Gerlach, 1978). As the abundance of the meiofauna might increase, its role in the 'small foodweb' will become more important.

\section{Acknowledgements}

The authors acknowledge the crews of the research vessels Welsinghe and Wijtvliet of the Dutch Rijkswaterstaat and Marris Stella of the Netherlands Institute of Ecology at Yerseke for their assistance in the field. Part of the research was supported by the Balans-project of Rijkswaterstaat. The second author acknowledges a grant from the Beyerinck-Popping fund. Contribution No. 697 of NIOO-CEMO, Yerseke, The Netherlands.

\section{References}

Alatalo, R. V., 1981. Problems in the measurement of evenness in Ecology. Oikos 37: 199-204.

Ansari, A. A., A. H. Parulekar \& T. G. Jagtap, 1980. Distribution of sublittoral meiobenthos off Goa Coast, India. Hydrobiologia 74: 209-214.

Arlt, G. \& M. A. H. Saad, 1977. Investigations on the meiofauna and sediment of the Shatt Al-Arab near Basrah (Iraq). Freshwat. Biol. 7: 487-494.

Austen, M. C. \& R. M. Warwick; 1989. Comparison of univariate and multivariate Aspects of estuarine 
meiobenthic community Structure. Estuar. coast. Shelf Sci. 29: 23-42.

Baird, D. \& H. Milne, 1981. Energy flow in the Ythan estuary, Aberdeenshire, Scotland. Estuar. coast. Shelf Sci. 13: 455-472.

Barnett, P. R. O., 1968. Distribution and ecology of harpacticoid copepods of an intertidal mudflat. Int. Revue ges. Hydrobiol. 53: 177-209.

Bodin, Ph., 1984. Densité de la méiofaune et peuplements de copépodes harpacticoĩdes en baie de Douarnenez (Finistère). Ann. Inst. océanogr. 60: 5-17.

Boucher, G., 1980. Facteurs d'équilibre d'un peuplement de nématodes des sables fins sublittoraux. Mém. Mus. natn. Hist. nat. 114: 1-81.

Bouwman, L. A., 1981. A survey of nematodes from the Ems estuary. Part I. Systematics. Zool. Jb. Syst. 108: 335-385.

Bouwman, L. A., 1983. A survey of nematodes from the Ems estuary. Part II. Species assemblages and associations. Zool. Jb. Syst. 110: 345-376.

Bowen, R. A., J. M. Onge, J. B. Colton \& C. A. Price, 1972. Density-gradient centrifugation as an aid to sorting planktonic organisms I. gradient materials. Mar. Biol. 14: 242247.

Buchanan, J. B. \& J. M. Kain, 1971. Measurements of the physical and chemical environment. In N. A. Holme \& A. D. McIntyre (eds), Methods for the study of marine Benthos, IBP-handbook nr. 16; Blackwell Oxford: 30-58.

Capstick, C. K., 1959. The distribution of free-living nematodes in relation to salinity in the middle and upper reaches of the River Blyth estuary. J. anim. Ecol. 28: 189-210.

Coull, B. C. \& J. B. J. Wells, 1981. Density of mud-dwelling meiobenthos from the sites in the Wellington region. N.Z. J. Mar. Freshw. Res. 15: 411-415.

Cullen, D. J. 1973. Bioturbation of superficial marine sediments by interstitial meiobenthos. Nature 242: 323-324.

Duursma E. K., H. Engel \& TH. J. H. Martens, 1982. De Nederlandse Delta. Natuur \& Techniek: 1-511.

Dye, A. H., 1983. Vertikal and horizontal distribution of meiofauna in mangrove sediments in Transkei, Southern Africa. Estuar. coast. Shelf Sci. 16: 591-598.

Dye, A. H. \& J. P. Furstenberg, 1978. An ecophysiological study of the meiofauna of the Swartkops estuary. 2. The meiofauna: composition, distribution, seasonal fluctuation and biomass. Zool. Afr. 13: 19-32.

Ellison, R. L., 1984. Foraminifera and meiofauna in an intertidal mudflat, Cornwall, England: populations, respiration and secundary production and energy budget. Hydrobiologia 109: 131-148.

Farris, R. A. \& H. Crezee, 1976. An improved Reineck box for sampling coarse sand. Int. Revue ges. Hydrobiol. 66: 703-705.

Faubel, A., 1982. Determination of individual meiofauna dry weight values in relation to definite size classes. Cah. Biol. Mar. 23: 339-345.

Faubel, A., E. Hartwig \& H. Thiel, 1983. On the ecology of the benthos of sublittoral sediments, Fladen Ground, North
Sea. I. Meiofauna standing stock and estimation of production. 'Meteor' Forsch.-Ergebnisse 36: 35-48.

Gee, J. M., 1987. Impact of epibenthic predation on estuarine intertidal harpacticoid copepod populations. Mar. Biol. 96: 497-510.

Gee, J. M., 1989. An ecological and economic review of meiofauna as food for fish. Zool. J. Linn. Soc. 96: 243-261.

Gerlach, S. A., 1953. Die biozönotische Gliederung der Nematodenfauna am der Deutschen Kusten. Z. morph. Ökol. Tiere 41: 411-512.

Gerlach, S. A., 1978. Food chain relationships in subtidal silty sand, marine sediments and the role of meiofauna in stimulating bacterial productivity. Oecologia 33: 55-69.

Heip, C., 1974. A new index measuring evenness. J. mar. biol. Ass. U.K. 54: 555-557.

Heip, C., R. Herman \& M. Vincx, 1984. Variability and productivity of meiobenthos in the Southern Bight of the North Sea. Rapp. P.-v. Réun. Cons. int. Explor. Mer 1983: 5156.

Heip, C., R. Herman, G. Bisschop, J. C. R. Govaere, M. Holvoet, D. Van Damme, C. Vanosmael, K. A. Willems \& L. De Coninck, 1979. Benthic studies of the Southern Bight of the North Sea and its adjacent continental estuarues. Progress Report I. International Report. International Council of the exploration of the Sea. C.M. 1979/L:9 Biological and Oceanography Committtee: 1-30.

Heip, C. \& N. Smol, 1976. The influence of temperature on the Reproductive Potential of two brackish-water Harpacticoids (Crustacea: Copepoda). Mar. Biol. 35: 327334.

Heip, C., K. A. Willems \& A. Goossens, 1977. Vertical distribution of meiofauna and the efficiency of the Van Veen grab on sandy bottoms in Lake Grevelingen (the Netherlands). Hydrobiol. Bull. 11: 35-45.

Herman, R., L. K. H. Thielemans \& C. Heip, 1984. Benthic studies of the Southern Bight of the North Sea. VIII. Evolution of the meiofauna in the belgian coastal waters from 1977 till 1983. Geconcerteerde Onderzoeksacties Oceanografie: progress report 1983: 1-19.

Hicks, G. R. F. \& B. C. Coull, 1983. The ecology of marine mejobenthic harpacticoid copepods. Oceanogr. Mar. Biol. annu. Rev. 21: 67-175.

Hill, M. O., 1973. Diversity and evenness: a unifying notation and its consequences. Ecology 54: 427-432.

Hodda, M. \& W. L. Nicholas, 1985. Meiofauna associated with Mangroves in the Hunter River Estuary and Fullerton Cove Southeastern Australia. Aust. J. mar. Freshwat. Res. 36: 41-50.

Hodda, M. \& W. L. Nicholas, 1986a. Temporal changes in littoral Meiofauna from the Hunter River Estuary. Austr. J. mar. Freshwat. Res. 37: 729-741.

Hodda, M. \& W. L. Nicholas, 1986b. Nematode diversity and industrial pollution in the Hunter River Estuary, NSW, Australia. Mar. Pollut. Bull. 17: 251-255.

Hostens, K. \& O. Hamerlynck, 1994. The mobile epifauna of the soft bottoms in the subtidal Oosterschelde estuary: 
structure, function and impact of the storm-surge barrier; Hydrobiologia 282/283: 479-496.

Jansson, B. O., 1966. Microdistribution of factors and fauna in marine sandy beaches. Veröff. Inst. Meeresforsch. Bremerh. 2: 77-56.

Little, C., 1986. Fluctuations in the meiofauna of the Aufwuchs community in a brackish-water lagoon. Estuar. coast. Shelf Sci. 23: 263-276.

Martens, P. M. \& E. R. Schockaert, 1981. Sand-dwelling Turbellaria from the Netherlands Delta Area. Hydrobiologia $84: 113-127$.

McIntyre, A. D., 1969. Ecology of marine meiobenthos. Biol. Rev. 44: 245-290.

McIntvre, A. D. \& D. J. Murison, 1973. The meiofauna of a flatfish nursery ground. J. mar. biol. Ass. U.K. 53: 93-118.

McLachlan, A., 1977. Studies on the psammolittoral meiofauna of Algao Bay, South Africa. II. The distribution, composition and biomass of the meiofauna and macrofauna. Zool. Afr. 12: 33-60.

Nienhuis, P. H. \& A. C. Smaal, 1994. The Oosterschelde estuary, a case study of a changing ecosystem: an introduction. Hydrobiologia 282/283: 1-14.

Nuss, B. 1984. Ultrastrukturelle und ökophysiologische untersuchungen an kristalloiden einschlüssen der muskeln eines sulfidtoleranten limnischen Nematoden (Tobrilus gracilis). Veröff. Inst. Meeresforsch. Bremerh. 20: 3-15.

Pihl, L., 1985. Food selection and consumption of mobile epibenthic fauna in shallow marine areas. Mar. Ecol. Progr. Ser. 2: 2: 169-179.

Platt, H M. \& R. M. Warwick, 1980. The significance of freeliving nematodes to the littoral ecosystem. In: J. H. Price, D. E. G. Irvine \& W. F. Farnham, (eds) The Shore Environment 2. Ecosystems. New York, Academic Press: 729759.

Raffaelli, D. \& F. Mason, 1981. Pollution monitoring with meiofauna, using the ratio of nematodes to copepods. Mar. Pollut Bull. 12: 158-163.

Reise, K., 1983. Experimental removal of lugworms from marine sand affects small zoobenthos. Mar. Biol. 74: 327-332.

Riemann, F., 1966. Die interstitielle Fauna im Elbe-aestuar. Verbreitung und Systematik. Arch. Hydrobiol., Supp. 31: $1-279$.

Saad, M. A. H. \& G. Arlt, 1977. Studies on the bottom deposits and the meiofauna of Shatt-al Arab and the arabian Gulf. Cah. Biol. mar. 18: 71-84.

Sherer, B. \& K. Reise, 1981. Significant predation on microand meiofauna by the crab Carcinus maenas $\mathrm{L}$. in the Wadden Sea. Kieler Meeresforsch. 5: 490-500.

Skoolmun, P. \& S. A. Gerlach, 1971. Jahreszeitliche Fluktuationen der Nematodenfauna im Gezeitenbereich des Weser-aestuar. Veröff. Inst. Meeresforsch. Bremerh. 13: 119-138.

Schmidt, P., 1978. Die quantitative Verteilung und Populationsdynamik des Mesopsammons am Gezeiten-Sandstrand der Nordseeinsel Sylt. I. Faktorengefuge und biolo- gisch Gliederung des Lebensraumes. Int. Revue ges. Hydrobiol. 53: 723-779.

Smol N., 1986. Rol van het meiobenthos in de Oosterschelde. Balans report, Delta Institute for hydrobiological Research: 1-151 (in Dutch).

Teal, J. M. \& W. Wieser, 1966. The distribution and ecology of nematodes in a Georgia salt marsh. Limnol. Oceanogr. 11: 217-222.

Tietjen, J. H., 1969. The ecology of shallow water meiofauna in two New England estuaries. Oecologia 2: 251-291.

Van Damme, D., C. Heip \& K. A. Willems. Influence of polIution on the harpacticoid copepods of two North Sea estuaries. Hydrobiologia 112: 143-160.

Van Damme, D., R. Herman, Y. Sharma, M. Holvoet \& P. Martens, 1980. Fluctuations of the meiobenthos communities in the Westerschelde estuary. Ices-report $\mathrm{CM} / \mathrm{L}$ 23: $131-170$.

Van Es F. B., M. A. van Arkel, L. A. Bouwman, H. G. J. Schröder, 1980. Influence of organic pollution on bacterial, macrobenthic and meiobenthic populations in intertidal flats of the Dollard. Neth. J. Sea Res. 14: 288-304.

Warwick, R. M., 1971. Nematode associations in the Exe estuary. J. mar. biol. ass. U.K. 51: 439-454.

Warwick, R. M. \& J. M. Gee, 1984. Community structure of estuarine meiobenthos. Mar. Ecol. Progr. Ser. 43: 213-219.

Warwick, R. M. \& R. Price, 1979. Ecological and metabolic studies on free-living nematodes from an estuarine mudflat. Estuar. coast. mar. Sci. 9: 259-271.

Willems, K. A., 1989. Verspreiding, ecologie en gemeenschapsstructuur van benthische copepoden in het Delta gebied en de Eems-Dollard (Nederland). Ph.D.-thesis, State University Gent: 1-440.

Willems, K. A. \& A. J. J. Sandee, 1978. Working group carbon cycle in the Grevelingen. The role of meiozoobenthos in the carbon cycle. In: E. K. Duursma (ed.), Progress Report 1977. Delta Insitute for Hydrobiological Research, Yerseke. Verh. kon. Ned. Akad. Wetensch. Natuurkunde 2: 28-30.

Willems, K. A. \& A. J. J. Sandee, 1979. Working group carbon cycle in the Grevelingen. Zoobenthos investigations. Meiozoobenthos: density and biomass. In: E. K. Duursma (ed.), Progress Report 1978. Delta Institute for Hydrobiological Research, Yerseke. Verh. Kon. Ned. Akad. Wetensch. Natuurkunde 2: 168-170.

Willems, K. A., Y. Sharma, C. Heip \& A. J. J. Sandee, 1984. Long-term evolution of the meiofauna at a sandy station in lake Grevelingen, the Netherlands. Neth. J. Sea Res. 18: 418-433.

Witte, J. IJ. \& J. J. Zijlstra, 1984. The meiofauna of a tidal flat in the western part of the Wadden Sea and its role in the benthic ecosystem. Mar. Ecol. Prog. Ser. 14: 129-138.

Wolff, W. J., 1973. The estuary as a habitat. An analysis of data on the soft bottom macrofauna of the estuarine area of the rivers Rhine, Meuse and Scheldt. Zool. Verh. 126: $1-242$. 